\title{
The Sydney Taylor Book Award at Fifty: Trends in Canonized Jewish Children's Literature (1968-2020)
}

\author{
Rachel Leket-Mor \\ Arizona State University Library \\ Fred Isaac \\ Temple Sinai, Oakland, CA
}

\section{ABSTRACT}

The Sydney Taylor Book Award, sponsored by the Association of Jewish Libraries since 1968 , is the only book award for children's literature that represents the Jewish experience. The award's fiftieth anniversary, celebrated in 2018, provided an opportunity to conduct a content analysis study of 102 books and summarize thematic and publishing trends across award categories and time periods. The data points collected were based on bibliographic records and, to smaller extent, on coded Holocaust-related themes. Conclusions refer to Jewish education in the United States and concepts of gender, identity, history, and Holocaust studies that have shaped it through children's literature for over fifty years.

Keywords: award books; children's literature; Jewish children's literature; Sydney Taylor Book Award; Holocaust education; gender in children's literature; publishing; quantitative research; content analysis

\section{Introduction ${ }^{1}$}

The Sydney Taylor Book Award (STBA), established by the Association of Jewish Libraries (AJL) in 1968, is named for the now-classic children's literature author Sydney Taylor (19041978), whose All-of-a-Kind Family book series was published in five installments between 1951 and 1978. The STBA Committee presents the annual gold and silver awards to "outstanding books for children and teens that authentically portray the Jewish experience” (AJL n.d.) and publishes a list of notable books. ${ }^{2}$

\footnotetext{
${ }^{1}$ The authors wish to thank Annette Goldsmith for her close reading of an early version of this paper.

${ }^{2}$ For its first decade it was named after Shirley Kravitz, a devoted proponent of children's Judaica. In 1978, after the death of Sydney Taylor, the award was named after her. For more information about the history of the award, see the "About" page on the AJL site (AJL n.d.) and Pinchuck 2008.
} 
The first identity-based award to celebrate children's literature, the STBA was described in June Cummins's 2017 book chapter (89), written in response to Nancy Larrick's 1962 article, "The All-White World of Children's Books," "3 which protests the lack of diversity in the national Newbery Award. Cummins's study, published in a volume dedicated to the cultural politics of children's book awards, sets the STBA in the identity studies theoretical framework by stating that, "book award committees are an institutional, functional, actual practice of identity studies, a place where identity studies come to life and into practice outside of academe," and clarifying what that practice is: "Of course that [calling for improvement in the world] is the aim of all identity-based book award committees. Indeed, the people who make up these committees are doing the work of social justice" (95). Cummins does not comment specifically on the STBA committee's work, but deems the non-profit PJ Library ${ }^{4}$ a successful project because of its proven ability to distribute free copies of out-of-print books and solicit new books and because it demonstrates, "how social activism can make changes in society, and more specifically, children's literature" (99-100). Referring to all identity-based children's book awards and their effectiveness in advancing social justice, Cummins observes, in what seems like an implicit criticism, that "the people on these committees do important work, and in the terms of the committees themselves, they are successful" (95).

The effectiveness of book awards in shaping identity has been challenged from the perspective of Jewish education. In a recently published volume that reconsiders the concept of Jewish identity, Tali Zelkowicz $(2019,145)$ draws on cultural studies and ethnographic research to assert that, "the Jewish community is nourished by the very conviction that educators and the educational institutions that employ them can actually excavate or even manufacture something called 'Jewish identity' for their learners." Referring to educators and indirectly to librarians, Zelkowicz calls this conviction a delusion, as "neither individuals nor institutions possess control over another's identity forming processes" (145). Specifically, Zelkowicz argues that "who gets to determine what counts as authentically Jewish" is a political question and that "Jewish identities are treated not only as products, but essentialized products. Consequently, they are rife with charged investments over what count as the 'right' components for the product" (155-156, italics in the original).

Our quantitative study of 102 gold medal-winning is neither engaged in making value judgments on what content authentically portrays the Jewish experience nor in evaluating the STBA selection criteria or their interpretation (see the committee's "How to Submit" page on AJL n.d.). Like other studies that have examined patterns in corpora of award-winning children's books - such as winners of the Newbery (Martin 1990; Bones 2010; Forest 2014), ${ }^{5}$ the Caldecott (Koss, John-

\footnotetext{
3 “The All-White World of Children's Books," by Nancy Larrick, The Saturday Review, 63-65, September 11, 1965; https://www.unz.com/print/SaturdayRev-1965sep11-00063/?View=PDF.

${ }^{4}$ https://pjlibrary.org/home.

${ }^{5}$ We were unable to access Kimberly Bartels Martin's 1990 master's thesis on representations of Jewish and Christian lifestyles in 62 Newbery award-winning books (1960-1990) due to the 2020 global pandemic. The work's citation includes a detailed abstract (see link under Sources), but is not cited in Cummins 2017.
} 
son, and Martinez 2018), the National Book Award (Bickmore, Xu, and Sheridan 2017), and the American Library Association (ALA) diversity awards (Rowland-Storm 2018) _our project employed content analysis methods to illuminate trends in 52 years' worth of awarded Jewish children's literature. ${ }^{6}$ Regardless of the problematic interconnections among award committee members, authors, and publishers (Kidd and Thomas 2017), the seal of excellence carried by the STBA books ascribes to them canonical status. As such, this collection of books serves as a suitable corpus for investigating cultural trends and values attributed to the Jewish way of life. The potential of this corpus has never been fully exploited: Only two previous studies explored small selections from it. Sigalow and Fox (2014) analyzed a sample of 30 STBA awarded picture books (1981-2011) for gender stereotypes and concluded that the books "promoted the image of the pious, domestic woman and the public, learned man [...] even if these stereotypes no longer reflect the increasingly egalitarian nature of contemporary American Jewish life" (428). In her 2010 article, "The Curious Conflation of Hanukkah and the Holocaust in Jewish children's Literature," Eichler-Levine referred in a footnote to the STBA corpus (winner, honor, and notable books; 112 fn 62) stating that, "out of 149 books honored by the awards since 1968, 39 have been directly about the Holocaust, while numerous other books have dealt with persecution in Russia and other regions." 7

The goal of this article is to outline trends in the STBA corpus of gold medal-winning books across time and award type. Our analysis is based on frequencies that emerged from both bibliographic data and our own coded scopes (three themes per book), and demonstrate how gender representations, plot settings, and the Holocaust are employed in canonized children's literature. We hope that our shared data sets may inspire others to expand this study and present a fuller picture of the Jewish literary landscape for English-speaking children, as recognized by AJL. Our readers are invited to examine and interpret the data on the priorities and values portrayed in these books, cherished by readers (primarily within the American-Jewish community), and promoted knowingly and unknowingly by the award committee.

\section{Methods}

The impetus to summarize the roughly one hundred books on the STBA gold medal list was the award's fiftieth anniversary in 2018, but by the time the manuscript was completed, additional books had been awarded and added to the corpus. The initial information collected for this project is freely available on the STBA Committee page on the AJL website (AJL n.d.) ${ }^{8}$ in the form of book lists. Using the ISBNs, we searched these titles in OCLC's WorldCat database and

\footnotetext{
${ }^{6}$ This project pertains to the STBA books only, although a manuscript award in Sydney Taylor's name has also been presented since 1985. For more information, see AJL n.d.

${ }^{7}$ The study examined ten books (1990-early 2000s), of which one was a STBA winning book: Seven books are listed on p. 96, fn 15; three additional ones are discussed on pp. 106-110. The publication dates are referred to on $\mathrm{p}$. 95. Eichler-Levine also made use of retailers lists such as Amazon or Barned and Nobles (2010,111-112). None of the 39 STBA books Eichler-Levine identified as Holocaust-related was named.

${ }^{8}$ The STBA Committee page provides both a chronological annotated list of all winners and a concise reference list, as well as additional information (AJL n.d.).
} 
captured their citations with the free Zotero citation manager. Since many books have multiple records in WorldCat, we had to choose which record to use and usually selected those records which had the most holdings. ${ }^{9}$ In some cases, we had to reconsider the use of WorldCat records initially selected. ${ }^{10}$ Finally, we exported these citations into a spreadsheet and based our analyses on its derivatives.

Our analyses focused on specific data points, some of which were part of the books' bibliographic records (e.g., publishers, page numbers, illustrators) and some we opted to add. The added data points were based on external information such as book reviews, summaries (Pinchuck 2008; 2018) and reader-based websites such as GoodReads. The major adjustments we made were related to Library of Congress Subject Headings (LCSH), which we decided to reduce to three ranked themes per book. This decision - not easy to implement at times - facilitated a streamlined analysis of major and secondary themes. In some cases, books were described by only two themes or even one. ${ }^{11}$ In these cases, we added placeholders ("no $2^{\text {nd }}$ theme," "no $3^{\text {rd }}$ theme") to represent the empty spaces. For the thematic reviews, we used both the major (first-level) theme and all-theme lists and we combined similar themes to create aggregated views. For example, we merged "emigration" and "immigration," or family-related themes such as "family life" and "cousins," into clusters to feature main thematic trends ("emigration/immigration;" and "family," respectively). We recognize that the data points we decided to explore and/or add reflect our own research interests.

The following three subsections record the process of collecting and preparing the data for our analyses. Each of the data sets is saved in a separate spreadsheet tab (raw data, clean data, and neat data). The neat data were used to create all subsequent tabs and the spreadsheets from which the tables and figures were made. All the spreadsheets available in the shared Google folder include the initial three tabs for reference. ${ }^{12}$

\footnotetext{
${ }^{9}$ Since WorldCat records are being constantly updated, the current records may not match our captured data, downloaded between August and October 2019.

${ }^{10}$ For example, in the case of Donna Jo Napoli's Storm, a retelling of the story of Noah and the Ark: The WorldCat record for this 2015 Teen Reader winner (\#850225486), available in 612 library catalogs, contains the following Library of Congress subject headings (LCSH): Survival, Animals, Noah's ark, Deluge "Juvenile Fiction - ReligiousChristian-Historical." This last LCSH represents a very particular reading of Napoli's book, which is detached from its original context, and therefore we replaced it with another record that has no such bias (\#966579812), although it had been downloaded by only 12 libraries. The original record (\#850225486) was updated on March 3, 2020, and it no longer contains that LCSH.

${ }^{11}$ We wrongly postulated that older books tended to have fewer LCSHs because of changing cataloging practices. The truth is that the Library of Congress has added subject headings, illustrators, and annotations to children's book since 1966 (Turner 1973; email communication with Ann Sullivan, children's literature cataloger at Library of Congress, May 5, 2020).

${ }^{12}$ Accessing this Google folder does not require a Google account. Readers can view all information, sort it (Data: Sort sheet by Column) and copy it, but not edit it: https://drive.google.com/drive/folders/1KNVC2xa_J5PT9U1jq45FcoNAyB e e4oba?usp=sharing.
} 


\section{Data Collection and Preparation (Raw Data)}

The bibliographic records were exported from WorldCat to Zotero, which rendered the LCSHs as "tags" in a single column of the spreadsheet. By splitting the LCSH into distinctive columns, we could count each of the LCSH separately.

\section{Data Cleanup and Enhancement (Clean Data)}

Bibliographic metadata were manually enhanced for better analysis results. These are the data affected:

- Award: We matched the old award categories (younger readers, older readers, and teen readers) with the ones updated in 2020 (picture book, middle-grade, and young adult, respectively); We created a separate category for the ten books awarded between 1968 and 1980 and named it original STB Award, to indicate that there were no age-specific categories at this time (although these chapter books probably belong with the Middle-grade category);

- Manual Tags (illustrators and translators): We eliminated this column and created separate columns for Illustrator and Translator;

- LCSH: We created new categories and a streamlined list of themes.

- Themes: We consulted the STBA committee's book summaries (AJL n.d.), book abstracts included on WorldCat (also exported to the spreadsheet), Pinchuck's (2018) annotations, and descriptions posted to GoodReads. The new columns (Theme 1, Theme 2, Theme 3) $\log$ three ranked themes per book; some of the themes are identical with LCSH and some are our own controlled vocabulary.

- Sub-themes: To better analyze the Holocaust-related prevalent theme, we assigned subthemes (e.g., Holocaust: children's fate, concentration camps); ${ }^{13}$

- We created new categories and added data where needed: Setting (where the story takes place), Protagonist (girl/s, boy/s, woman/women, man/men), Genre (such as fiction, biography, biblical story retelling), and Format (used sparingly, for example: anthology, pop-up); added missing information, such as number of pages; and eliminated all word declensions related to Jewish literature (e.g., jews, jewish) since our corpus is based on this genre, and words that indicate format or audience (e.g., juvenile, fiction, young, adult).

\section{Workable Data (Neat Data)}

In this final step, we removed information unnecessary for our analysis: LCSHs, OCLC numbers, and old award categories (Younger Readers, Older Readers, and Teen Readers. We unified publishers' names (e.g. Alfred A. Knopf and A.A. Knopf); ${ }^{14}$ and adjusted the three themes representing each book.

\footnotetext{
${ }^{13}$ We thank Joseph (Yossi) Galron-Goldschläger for his suggestion to sub-categorize the Holocaust-related themes.

${ }^{14}$ We refrained from sorting out publisher subsidiary companies for this study.
} 


\section{Findings: The Sydney Taylor Book Award in Numbers}

From 1968 to 2020, a total of 102 books were awarded the STBA gold medal. Most of the awarded works ( 86 percent) were either picture books (introduced in 1981; 39 percent) or middle-grade books (37 percent). The disproportionately low number of winners in the young adult category (14 percent) is due to the fact that the award was instituted only in 2007. Ten books written for children between eight and 14 years of age (third to eighth grades; termed "middle-grade" in 1981) won the award before any categories had been introduced (1968-1980). During these formative years, only one award was given annually, and no book was awarded at all in 1971, 1972, and 1974 (Table 1). In the following decades, about 20 books were awarded per decade-with two exceptions. In 2005 (the fourth period), the award year became the same as the publishing year (instead the previous publishing year), which resulted in 23 awards; ${ }^{15}$ and the last decade (2010-2020) saw a 10 percent increase in the number of awarded books because the new young adult category had been added (Table 2). The average number of pages of winning STBA books in the picture book category was 40 ; in the middle-grade category, 168; and in the young adult category, 313.

Table 1. STBA winners, by award type

\begin{tabular}{lc} 
Award & $\begin{array}{l}\text { Number } \\
\text { of Books }\end{array}$ \\
\hline $\begin{array}{l}\text { Picture Book } \\
(1981-)\end{array}$ & 40 \\
$\begin{array}{l}\text { Middle Grade } \\
(1981-)\end{array}$ & 38 \\
$\begin{array}{l}\text { Young Adult (2007-) } \\
\begin{array}{l}\text { Original STB Award } \\
(1968-1980)\end{array}\end{array}$ & 14 \\
\cline { 2 - 2 } & 102
\end{tabular}

Table 2. STBA winners, by time period

\begin{tabular}{cc} 
Time Period & $\begin{array}{c}\text { Number } \\
\text { of Books }\end{array}$ \\
\hline $1968-1980$ & 10 \\
$1981-1990$ & 20 \\
$1991-1999$ & 19 \\
$2000-2009$ & 23 \\
$2010-2020$ & 30 \\
\cline { 2 - 2 } & 102
\end{tabular}

\section{GenRes}

The majority of the STBA recipients (72 percent) were works of fiction, including sub-categories such as retelling historical fiction. Folktales represented 9 percent of STBA winners, most of them picture books. Far behind these prominent genres, biographies constituted 10 percent of the awarded books. Interestingly, no biography won the STBA for young adults and few books of poetry or nonfiction won the award in any category (Table 3$).{ }^{16}$

\footnotetext{
${ }^{16}$ Some of the genres included, such as comic books and movable books are actually formats.
} 
R. Leket-Mor and F. Isaac / Judaica Librarianship 21 (2020) 58-94

Table 3. STBA winners' distribution by genre and category

\begin{tabular}{|c|c|c|c|c|c|}
\hline Genre & $\begin{array}{c}\text { Original } \\
\text { STB Award }\end{array}$ & $\begin{array}{l}\text { Picture } \\
\text { Book }\end{array}$ & $\begin{array}{c}\text { Middle } \\
\text { Grade }\end{array}$ & $\begin{array}{l}\text { Young } \\
\text { Adult }\end{array}$ & Total \\
\hline Fiction & 8 & 21 & 29 & 11 & 69 \\
\hline $\begin{array}{l}\text { Historical } \\
\text { fiction }\end{array}$ & & & 1 & 1 & 2 \\
\hline $\begin{array}{l}\text { Biblical story } \\
\text { retelling }\end{array}$ & & 1 & & & 1 \\
\hline $\begin{array}{l}\text { Fictional } \\
\text { retelling }\end{array}$ & & 1 & & & 1 \\
\hline Total fiction & 8 & 23 & 30 & 12 & 73 \\
\hline Biography & 1 & 5 & 4 & & 10 \\
\hline Folktale & & 8 & 1 & & 9 \\
\hline $\begin{array}{l}\text { Graphic novel/ } \\
\text { Comic book }\end{array}$ & & 1 & 2 & & 3 \\
\hline Nonfiction & 1 & 1 & & & 2 \\
\hline Prayer & & 1 & & & 1 \\
\hline Diary & & & & 1 & 1 \\
\hline $\begin{array}{l}\text { Epistolary } \\
\text { Novel }\end{array}$ & & & & 1 & 1 \\
\hline Poetry & & & 1 & & 1 \\
\hline $\begin{array}{l}\text { Toy and mov- } \\
\text { able books }\end{array}$ & & 1 & & & 1 \\
\hline Grand Total & 10 & 40 & 38 & 14 & 102 \\
\hline
\end{tabular}

\section{Authors and IlLustrators}

The 102 books were written by 90 individual authors. Of the 12 authors who won the STBA twice, three wrote picture books (Eric Kimmel, Richard Michaelson, and Elsa Rael), and one author (Karen Hesse) wrote two winning middle-grade books. Sonia Levitin and Donna Jo Napoli each wrote one middle-grade and one young adult book, while Patricia Polacco, Maxine Schur, and Howard Schwartz each wrote one middle-grade and one picture book (Table 4). Analyzed by award category, the two-time winning authors wrote 11 (29 percent) middle-grade books, 10 (25 percent) picture books, 2 (14 percent) young adult books; and one (10 percent) original STBA book.

About half of the winning books were illustrated: one each of the original STB award and young adult books, 12 of the middle-grade books ( 32 percent), and 35 of the picture books ( 88 percent; some of their records don't include the illustrator's name). Most of the illustrators contributed to a single book, but three illustrated two books each: Charles Robinson, Elivia Savadier, and Kristina Swarner. 
Table 4. STBA twice-winning authors, by award category

\begin{tabular}{|c|c|c|c|c|}
\hline Author & $\begin{array}{c}\text { Original STB } \\
\text { Award }\end{array}$ & $\begin{array}{c}\text { Picture } \\
\text { Book }\end{array}$ & $\begin{array}{l}\text { Middle } \\
\text { Grade }\end{array}$ & $\begin{array}{l}\text { Young } \\
\text { Adult }\end{array}$ \\
\hline Hesse, Karen & & & 2 & \\
\hline Jaffe, Nina & & 1 & 1 & \\
\hline Kimmel, Eric A. & & 2 & & \\
\hline Levitin, Sonia/ Levitin, Sonia & & & 1 & 1 \\
\hline Michelson, Richard & & 2 & & \\
\hline Napoli, Donna Jo & & & 1 & 1 \\
\hline Polacco, Patricia & & 1 & 1 & \\
\hline Rael, Elsa & & 2 & & \\
\hline Schur, Maxine (Schur, Maxine Root) & & 1 & 1 & \\
\hline Schwartz, Howard / Schwartz, Howard; Rush, Barbara & & 1 & 1 & \\
\hline Snyder, Carol & 1 & & 1 & \\
\hline Vos, Ida & & & 2 & \\
\hline Total & 1 & 10 & 11 & 2 \\
\hline
\end{tabular}

\section{TransLations}

Eight award-winning books were translated from other languages (Figure 1), half of them intended for middle-grade readers. Two books were translated from the Dutch (both written by Ida Vos and translated by Terese Edelstein; three from the French; two from the Hebrew; and one from the Spanish. Seven translations won the STBA between 1995 and 2017, three of them over a four-year period (2014-2018). This trend indicates a growing awareness of, as well as better access to world literature over time. The scarcity of STBA translated titles is probably due to American publishers' reluctance to invest in translated literature. Houghton Mifflin is the only publisher that issued more than one translated winner (Dutch and Hebrew); the other publishers were HarperCollins (Dutch); Bloomsbury, First Second, and Walker (French); Kar-Ben, Seven Stories Press (Hebrew); and Godwin Books/Henry Holt and Company (Spanish).

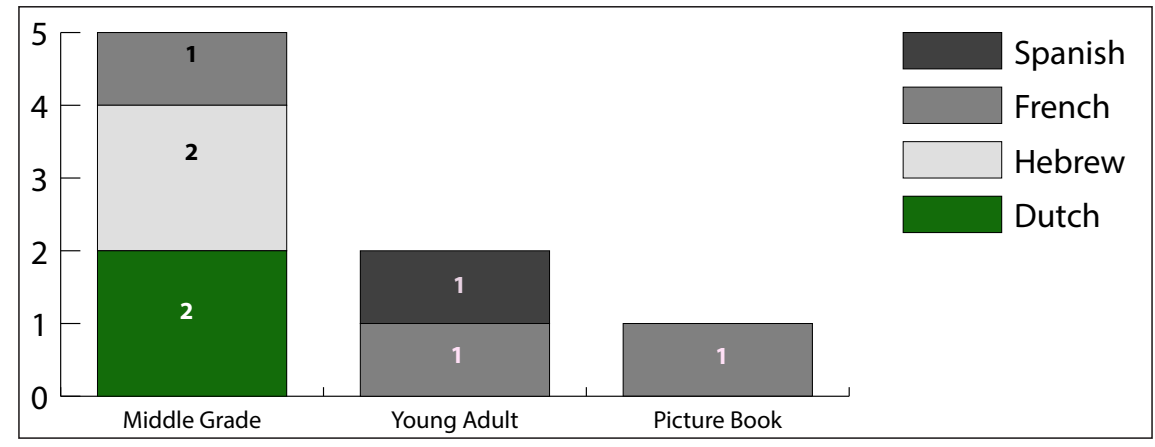

Figure 1. Distribution of source languages and award types, STBA 9 translated books 


\section{Publishers}

In all, 56 publishers issued the STBA books. Knopf led the way with eight books (most of them for young adults), followed by Simon \& Schuster with seven books (most of them, picture books), Dutton Books and Scholastic with five books each (most of them middle-grade and picture books, respectively), and Houghton Mifflin with four picture books. Of the nine most awarded publishers (with more than three awarded books each; Figure 2), specialized publishers (Jewish Publication Society and Kar-Ben) take the last place, while national publishing houses take the lion's share. None of these national publishers is represented among the original STBA winning books, which may indicate the success of the award in attracting big names into the domain starting in the 1980s. Fourteen publishers each put out two STBA winning books, while 33 companies published one book each.

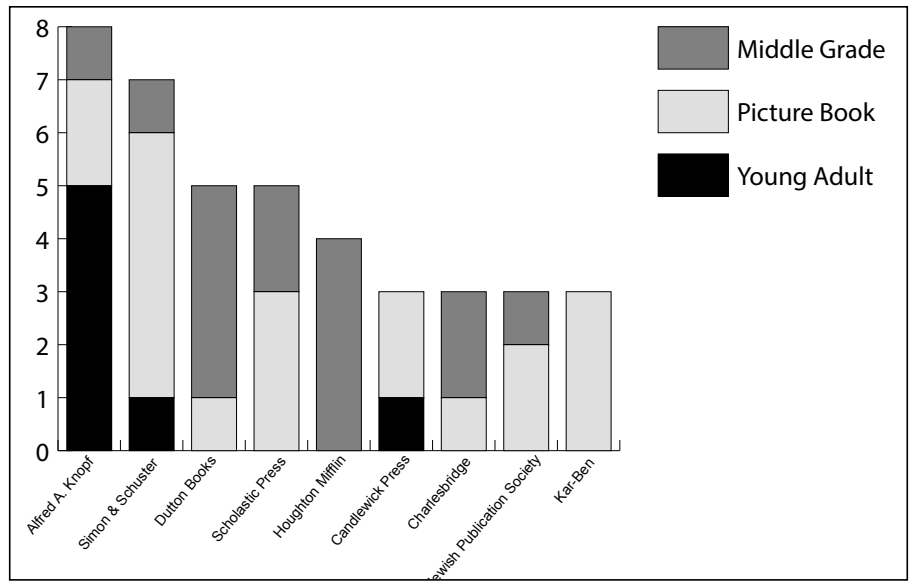

Figure 2. Publishers with more than three STBA books, by award category

\section{Award Trends: A Chronological Review}

The STBA winning books across five time periods, roughly matching the five decades of awarding activity, present three reoccurring themes, which vary somewhat in relative frequency over the years: The Holocaust, Emigration and immigration, and Family. These themes, which do not constitute the majority of the corpus but do represent unmistakable trends, are noticeable on both the measurements we used for this study (Table 5, 6): the three most frequent themes when considering one major theme per book, and the three most frequent themes when weighting all the themes (the theme lists for all time periods are available in the appendix, Table 16-23; some of the books had fewer than three themes). The Holocaust becomes an overarching theme over time, from second place in the 1980s to first place in the following decades, to occupying both first and second places in the most recent decade. The next most prominent topics after the Holocaust are holiday-related themes, folkloric stories, and legends, which occupy the second and third place from the 1980s to the late 2000s. Emigration/immigration and antisemitism have not characterized STBA books since the 1990s, but family ties and friendship make a comeback from the 1970s in the current decade. When weighting all the themes, the Family theme surfaces in all periods and Holidays lose their prominence in comparison with the first-level theme. 


\section{The First Decade: 1968-1980 (10 Books)}

Of the ten chapter-books that won the original book award before any categories were introduced (1968-1980), five were related to immigration and emigration. Three of them told the story of coming to America and/or leaving Europe: Marietta Moskin's Waiting for Mama (1975) recounts

Table 5. Most frequent major themes, by time period

\begin{tabular}{|c|c|c|c|c|c|}
\hline $\begin{array}{c}\text { Frequency } \\
\text { Level }\end{array}$ & $\begin{array}{c}\text { 1968-1980 } \\
10 \text { Books/Themes }\end{array}$ & $\begin{array}{c}\text { 1981-1990 } \\
20 \text { Books/Themes }\end{array}$ & $\begin{array}{c}\text { 1991-1999 } \\
19 \text { Books/Themes }\end{array}$ & $\begin{array}{c}\text { 2000-2009 } \\
23 \text { Books/Themes }\end{array}$ & $\begin{array}{c}\text { 2010-2020 } \\
30 \text { Books/Themes }\end{array}$ \\
\hline 1 & Family & $\begin{array}{l}\text { Emigration / } \\
\text { immigration }\end{array}$ & Holocaust & Holocaust & Holocaust: survival \\
\hline 2 & Antisemitism & Holocaust & Holidays & Holidays & Holocaust \\
\hline 3 & $\begin{array}{l}\text { Emigration / } \\
\text { immigration }\end{array}$ & $\begin{array}{l}\text { Holidays, } \\
\text { Legends }\end{array}$ & Folklore/ Legends & $\begin{array}{l}\text { Caring \& } \\
\text { friendship }\end{array}$ & Family \\
\hline
\end{tabular}

Table 6. Most frequent themes, by theme level and time period

\begin{tabular}{|c|c|c|c|c|c|}
\hline $\begin{array}{c}\text { Theme } \\
\text { Level }\end{array}$ & $\begin{array}{l}1968-1980 \\
24 \text { Themes }\end{array}$ & $\begin{array}{l}1981-1990 \\
52 \text { Themes }\end{array}$ & $\begin{array}{l}\text { 1991-1999 } \\
48 \text { Themes }\end{array}$ & $\begin{array}{l}\mathbf{2 0 0 0 - 2 0 0 9} \\
60 \text { Themes }\end{array}$ & $\begin{array}{l}\text { 2010-2020 } \\
81 \text { Themes }\end{array}$ \\
\hline 1 & $\begin{array}{l}\text { Emigration / } \\
\text { immigration }\end{array}$ & Family & Holocaust & Holocaust & $\begin{array}{l}\text { Holocaust: } \\
\text { survival }\end{array}$ \\
\hline 2 & Family & Holocaust & Family & $\begin{array}{l}\text { Friendship, } \\
\text { Interpersonal } \\
\text { relations }\end{array}$ & Holocaust \\
\hline 3 & Holocaust & $\begin{array}{l}\text { Emigration / } \\
\text { immigration }\end{array}$ & Holidays & Family & Literacy \\
\hline
\end{tabular}

the story of a family that arrives in America and prepares for the arrival of their mother and baby sister. Anita Heyman's Exit from Home (1977) describes the struggles of a rabbinical student in Tsarist Russia as he faces antisemitism and the modern world for the first time. Everett Fisher's Russian Farewell (1980) vividly describes a pogrom and its effects on a Russian family and ends with the family's departure for America. Carol Snyder's Ike and Mama and the Block Wedding (1979, part of a series) describes life in Jewish Harlem in the 1920s or 1930s, and the community spirit that grew among the many ethnic communities there. Shulamith Ish-Kishor's Our Eddie (1969) tells the tragic story of a couple and their autistic son Eddie who lived in London and New York during the postwar decade from 1945 to 1955.

Four books were related to the Holocaust: Esther Hautzig's The Endless Steppe: Growing up in Siberia (1968) recounts the travails of the author's family in Soviet Siberia, and is a powerful reminder of the extended tentacles of war. The other Shoah-related books were Milton Melt- 
zer's Never to Forget (1976), a nonfiction history of the Nazi era; Doris Orgel's Devil in Vienna (1978), a tale of shattered friendship; and Yuri Suhl's Uncle Misha's Partisans (1973), the story of a boy's role in the fight against the Nazis (Table 7).

\begin{tabular}{|c|c|c|c|}
\hline Major Themes (10) & Frequency & All Themes (24) & Frequency \\
\hline Family & 3 & $\begin{array}{l}\text { Emigration and } \\
\text { immigration }\end{array}$ & 5 \\
\hline Antisemitism & 2 & Family & 4 \\
\hline $\begin{array}{l}\text { Emigration and immi- } \\
\text { gration }\end{array}$ & 2 & Holocaust & 4 \\
\hline Holocaust & 1 & Antisemitism & 3 \\
\hline Friendship & 1 & Friendship & 2 \\
\hline \multirow[t]{6}{*}{ Kibbutz } & 1 & Coming of age & 1 \\
\hline & & Disabled children & 1 \\
\hline & & $\begin{array}{l}\text { Interpersonal } \\
\text { relations }\end{array}$ & 1 \\
\hline & & $\begin{array}{l}\text { Politics and gov- } \\
\text { ernment }\end{array}$ & 1 \\
\hline & & Slave labor & 1 \\
\hline & & Kibbutz & 1 \\
\hline
\end{tabular}

\section{The Second Decade: 1981-1990 (20 Books)}

Beginning in 1981, a second category was instituted to award books for younger readers, primarily picture books for children up to age six or seven. The new category created an expectation of excellence parallel to that of the major American prize for children's literature, the Newbery Award. The classification also brought new sensitivities regarding the appropriateness of the Holocaust and other emotional issues as subject matter for young children (see also Haas and Haas 2008).

Immigrant life and emigration were again the focus of the STBA winners. Two of them are picture books: Linda Heller's The Castle on Hester Street (1982) and Esther Blanc's Berchik (1982). Marilyn Sachs's Call me Ruth (1982) and Carol Snyder's Ike and Mama and the Seven Surprises (1985) are for older readers. Snyder was the first author to receive the original STB award twice, for books in the Ike and Mama series. It is noteworthy that Berchik takes place in the American West, while the other three are set in New York. Interestingly, all the stories have universal themes, rather than specifically Jewish ones. Four other books treat themes of life before (and while) the protagonists leave their original homes. Patricia Polacco's Keeping Quilt 
(1988) tells how her family has cherished a treasured keepsake over generations. In Kathryn Lasky's Night Journey (1981), the teenaged heroine gives up a coveted role in "Oklahoma" to hear her great-grandmother talk about how her family left Russia. Sonia Levitin's Return (1987) recounts the harrowing journey of an Ethiopian girl from her home in Africa to make aliyah to Israel. Nancy Pitt's Behind the High White Wall (1986) begins with a pogrom and ends with a family's traveling to America; its protagonist is a girl who challenges her family and friends to leave their home, rather than suffer further persecution. In all, eight books (40 percent) about emigration and immigration were awarded, but unlike the in original STBA-winning books, antisemitism was not their focus and it did not emerge as a first-level theme.

Five books focused on the Holocaust: David Adler's The Number on My Grandfather's Arm (1987) is a picture book that treats the topic with respect and compassion. Each of the four others, for older children, has its own important lessons. Lois Lowry's Number the Stars (1989) and Jane Yolen's The Devil's Arithmetic (1988) remain standards in the Shoah genre. Uri Orlev's The Island on Bird Street (1984) is the tale of a boy who watches the war from a secret hiding place. Rose Zar's In the Mouth of the Wolf (1983) tells of the author's experiences throughout the horrors. Death - another difficult topic - is also a principal theme, despite questions about its suitability for young children. Barbara Pomerantz's Bubby, Me and Memories (1983) is a sensitive and powerful exploration of this topic. It remains part of the Shoah canon, with its photographs etched in the minds of both parents and children over two generations (Table 8).

Holidays and traditional content such as legends constitute another thematic cluster, and are represented by six books (30 percent). Florence Freedman's Brothers (1985) retells a talmudic legend in which a crisis brings out the best in people. Adele Geras's My Grandmother's Stories (1990) is an anthology of folk tales, remembered through evocations of the author's childhood in

Table 8. STBA books (1981-1990): Major themes and all themes, aggregated views (20 books)

\begin{tabular}{|c|c|c|c|}
\hline Major Themes (20) & Frequency & All Themes (52) & Frequency \\
\hline $\begin{array}{l}\text { Emigration and } \\
\text { immigration }\end{array}$ & 5 & Family & 9 \\
\hline Holocaust & 5 & Holocaust & 8 \\
\hline Holidays, Legends & 4 & $\begin{array}{l}\text { Emigration and } \\
\text { immigration }\end{array}$ & 7 \\
\hline Family life & 2 & $\begin{array}{l}\text { Folklore \& Holi- } \\
\text { days }\end{array}$ & 7 \\
\hline Shabbat & 2 & Antisemitism & 3 \\
\hline Death & 1 & Friendship & 2 \\
\hline \multirow[t]{3}{*}{ Ethiopian Jews } & 1 & $\begin{array}{l}\text { Personal Narra- } \\
\text { tive }\end{array}$ & 2 \\
\hline & & Shabbat & 2 \\
\hline & & $\begin{array}{l}\text { Non-frequent } \\
\text { themes }\end{array}$ & 12 \\
\hline
\end{tabular}


Europe. Four picture book winners feature Jewish holidays. Two titles, Marilyn Hirsh's Joseph Who Loved the Sabbath (1986) and Amy Schwartz's Mrs. Moskowitz and the Sabbath Candlesticks (1984) are specific Shabbat stories, each with its own moral to impart. The Chanukkah Guest (1990) is a shtetl tale by Eric Kimmel. The last, Yussel's Prayer by Barbara Cohen (1981), retells a Baal Shem Tov story of how holiness can come from unexpected sources. Still, the most frequent trend that emerges from the all-theme analysis is none of the above but the family as a cohesive force in the life of Jewish children.

\section{The Third Decade: 1991-1999 (19 Books)}

During the 1990s, the themes of the previous decade's winning books continued, with a more somber tone in evidence. Two books dealt directly with death and in a third, death was a primary sub-theme. Sandy Lanton's Daddy's Chair (1991) powerfully shows a young boy coming to terms with his father's absence. Sheldon Oberman's Always Prayer Shawl (1994) treats the topic more obliquely through the passing down of a ritual object: a boy receives a tallith from his grandfather and later repairs it to give to his own grandson. The assassination of Yitzhak Rabin is the focus of Barbara Sofer's Shalom, Chaver: Goodbye, Friend (1996). This touching biography was also the only Israel-focused recipient of the decade. Of the 19 awarded books, five focus on the Holocaust. Notably, two of them are picture books. Jo Hoestlandt's Star of Fear, Star of Hope (1995) and Marci Stillerman's Nine Spoons (1998) tell of distressing experiences, one of a best friend taken away and the other a tale from a camp. Ida Vos's Dancing on the Bridge of Avignon (1995) recounts the story of a child who was hidden, as the author had been. Steven Schnur's Shadow Children (1994) is an eerie story about the massacre of a train filled with Jews and the afterlife of the children who died. Donna Jo Napoli's Stones in Water (1998) describes the harrowing life of an Italian boy swept up in a Nazi raid, his years in prison camps, and his long journey home.

Two books focus on immigration or emigration: Karen Hesse's Letters from Rifka (1992) is a touching novel of correspondence; Rifka writes to her cousin in Europe about her family's escape from Russia, and her experiences after they leave her behind in Belgium and sail to America. Brian Pinkney's When I Left my Village (1996) recounts the experiences of an Ethiopian Jewish teen as he leaves home for Israel. Two recipients of the young adult book award focused specifically on coming of age and the unique challenges young people face at that life juncture. Sybil Rosen's Speed of Light (1999) takes the reader to the American South in the late 1950s, when local race relations merge with her aunt's experience in the Holocaust. Carol Matas's Sworn Enemies (1993) tells about a boy who is stolen from his home and conscripted into the Czar's army.

In the 1990s three anthologies of legends and stories (16 percent) won the top Sydney Taylor Book Award. No award since then has gone to an anthology. Howard Schwartz and Barbara Rush's The Diamond Tree was awarded in 1991 and later in the decade, Nina Jaffe was awarded twice, in 1993 for The Uninvited Guest and in 1997, for The Mysterious Visitor. 
Two individual tales received the award for picture books. Phoebe Gilman's Something from Nothing (1992) reminds the reader of the value of reusing treasured objects for new purposes. Kimberley Root's Peddler's Gift (1999) tells about the power of teshuvah and shows the hidden depth of those who pass through our lives. Only two picture books about holidays (11 percent) received the award. Barbara Diamond Goldin's Cakes and Miracles (1991) is a touching Purim story about finding unexpected gifts and talents. Elsa Rael's When Zaydeh Danced on Eldridge Street describes how a young girl sees her dour grandfather in a new light during the joyful celebration of Simchat Torah. For the first time, there was a tie: in 1991, Sandy Lanton and Barbara Diamond Goldin shared the award for Younger Readers. The all-theme analysis demonstrates again the underlying theme of family, this time as the second-most frequent theme after the Holocaust, which takes first place on both theme-based analyses (Table 9).

Table 9. STBA books (1991-1999): Major themes and all themes, aggregated views (19 books)

\begin{tabular}{|c|c|c|c|}
\hline Major Themes (19) & Frequency & All Themes (48) & Frequency \\
\hline Holocaust & 5 & Holocaust & 8 \\
\hline Holidays & 3 & Family & 5 \\
\hline Antisemitism & 1 & Holidays & 5 \\
\hline Coming of age & 1 & Folklore & 5 \\
\hline Death & 1 & $\begin{array}{l}\text { Emigration and } \\
\text { immigration }\end{array}$ & 3 \\
\hline Elijah & 1 & Escape & 2 \\
\hline Emigration & 1 & Death & 2 \\
\hline Ethiopian Jews & 1 & $\begin{array}{l}\text { Non-frequent } \\
\text { themes }\end{array}$ & 17 \\
\hline Folklore & 1 & & \\
\hline Israel & 1 & & \\
\hline Legends & 1 & & \\
\hline Peddlers & 1 & & \\
\hline Ritual objects: Tallith & 1 & & \\
\hline
\end{tabular}




\section{The Fourth Decade: 2000-2009 (23 Books)}

The new millennium began with two second-time award recipients, Ida Vos and Eric Kimmel. The decade also saw the introduction of a new award category: the teen readers book (2007; the category was renamed in 2020 to match ALA's young adult award). The first recipient, Markus Zusak's The Book Thief, has become a cross-over phenomenon, as it is frequently chosen by adult book groups. Also, for the first time since the 1970s, no younger reader award was presented in 2004.

Five Holocaust-related books ( 25 percent) received the award, including some new takes on the theme. Karen Levine's Hana's Suitcase (2002) is a double story, covering both the young victim and the search for her traces fifty years later by the Tokyo Holocaust Museum's director. Ida Vos's The Key is Lost (2000) is her second story about a hidden child. Nancy Patz's Who Was the Woman (2003) is an extended contemplation of a hat seen in a United Stated Holocaust Memorial Museum. Sid Fleischman's The Entertainer and the Dybbuk (2008) is a surprising take on Nazi-hunting after the war, in which the Holocaust is a third-level theme. Finally, the inaugural winner of the young adult award, Markus Zusak's The Book Thief (2007), was also focused on the Holocaust.

Jewish holidays were represented in three award-winning picture books, among them Eric Kimmel's Gershon's Monster (2000), a tender yet powerful picture book concerned with forgiveness and Yom Kippur. Also awarded was a book about a prayer: Sarah Gershman's Bedtime Sh'ma (2008) is both a gentle bedtime story and a teaching device for parents and children. Traditional food was an underlying theme in several otherwise unrelated books. It formed the basis of Julia's Kitchen, was integral to Rivka's First Thanksgiving, and was the subject of two younger readers' award-winning books: Esther Hershenhorn's Chicken Soup by Heart (2002) is the story of a boy who wants to help his elderly neighbor get well and Aubrey Davis's Bagels from Benny (2003) recounts a traditional tale about helping others anonymously. Immigration and emigration stories were also award winners. Karen Hesse's Brooklyn Bridge (2009) follows a teenager newly arrived in New York after the Holocaust. Elsa Rael's Rivka's First Thanksgiving (2001) intertwines American traditions with an immigration story and Jewish heritage. American history is featured in two titles for younger readers, both based on true events: Richard Michelson's As Good As Anybody: March Toward Freedom (2009) tells the story of the relationship between Martin Luther King and Rabbi Abraham Joshua Heschel; and Stephen Krensky's Hanukkah at Valley Forge (2007) recounts a visit by George Washington to a Jewish soldier during Hanukkah.

For three consecutive years, coming-of-age stories won the award in the older readers category. In each of these books, a teenager struggles with her identity and explores her relationships with others and her duties to them. Sarah Littman's Confessions of a Closet Catholic (2006) deals with religious belief; Brenda Farber's Julia's Kitchen (2007) focuses on life after the death of a parent; and Sonia Levitin's Strange Relations, (2008) reflects on adult responsibilities. 
Table 10. STBA books (2000-2009): Major themes and all themes, aggregated views (23 books)

\begin{tabular}{|c|c|c|c|}
\hline $\begin{array}{l}\text { Major Themes } \\
(23)\end{array}$ & Frequency & All Themes (60) & Frequency \\
\hline Holocaust & 4 & Holocaust & 8 \\
\hline Holidays & 3 & $\begin{array}{l}\text { Friendship, Inter- } \\
\text { personal relations }\end{array}$ & 5 \\
\hline $\begin{array}{l}\text { Caring and friend- } \\
\text { ship }\end{array}$ & 2 & Family & 4 \\
\hline Coming of age & 2 & $\begin{array}{l}\text { American culture, } \\
\text { history }\end{array}$ & 3 \\
\hline Death/ Sickness & 2 & Holidays & 3 \\
\hline Family & 2 & $\begin{array}{l}\text { Judaism, Religion, } \\
\text { Prayers }\end{array}$ & 3 \\
\hline $\begin{array}{l}\text { Arab-Israeli con- } \\
\text { flict }\end{array}$ & 1 & $\begin{array}{l}\text { Social justice, Civil } \\
\text { rights, Toleration }\end{array}$ & 3 \\
\hline Catholic Church & 1 & Coming of age & 2 \\
\hline Dybbuk & 1 & Identity & 2 \\
\hline Immigration & 1 & Cultural concepts & 2 \\
\hline Prayers & 1 & Death, Sickness & 2 \\
\hline Psychoanalysis & 1 & $\begin{array}{l}\text { Dybbuk, Ghost } \\
\text { stories }\end{array}$ & 2 \\
\hline Social justice & 1 & Immigration & 2 \\
\hline \multirow[t]{4}{*}{ Yiddish language } & 1 & Literacy & 2 \\
\hline & & Psychoanalysis & 2 \\
\hline & & Traditional foods & 2 \\
\hline & & $\begin{array}{l}\text { Non-frequent } \\
\text { themes }\end{array}$ & 13 \\
\hline
\end{tabular}

Unlike in earlier years of the STBA, this period's winners included four biographies (20 percent). In addition to Michelson's book for younger readers and Hana's Suitcase, were Sholom 's Treasure (2006), which tells about Sholom Aleichem's youth in Russia, and Catherine Reef's long-form, lavishly-illustrated biography of Sigmund Freud (2001), which provides a wealth of information for both older children and adult readers in accessible language (Table 10). 
The two winning books that were set in Israel (10 percent) explore challenging situations: Pnina Kass's Real Time (2004) is a fictional retelling of a bus bombing and its aftermath from several perspectives. Valérie Zenatti's Bottle in the Gaza Sea (2009) asks whether Jewish and Arab teens can fall in love.

The breadth of subjects treated in this decade's winning titles is reflected in the analyses. Family, friendship and interpersonal relations again constitute subtexts that support many of the STBA narratives.

\section{The Fifth Decade: 2010-2020 (30 Books)}

Books published after 2010 became more multidimensional and complex, which is reflected in the larger number of themes identified among the award-winning titles (Table 20, appendix). Still, the Holocaust remained a backdrop or a prominent theme in nine books. The nonfiction selections included a biography of Raoul Wallenberg (2013) and a retelling of the Israeli capture of Adolf Eichmann (2014). Among the novels were several books about survival: Gavriel Savit's near-fantasy Anna and the Swallow-Man (2017), a translated novella by Aharon Appelfeld (2016), and Vesper Stamper's What the Night Sings (2019), which begins where most Holocaust novels close: at the end of World War II. The story tells of life in the DP camps and of the emotional growth of the teenaged protagonist. Rob Sharenow's 2012 award-winning novel, The Berlin Boxing Club, is based on the boys' club established by Max Schmeling, the great heavyweight boxer who assisted Jews during the Nazi era. Margarita Engle's Tropical Secrets (2010) recounts the abortive voyage of the S.S. St. Louis as it sat in Havana Harbor with its crew and refugee passengers on board. The story is told entirely as a series of short poems sent between a Jewish boy and a Cuban girl. The 2018 recipient for teen readers, Antonio Iturbe's The Librarian of Auschwitz, translated from the Spanish, tells of the small cache of books kept in the girls' dormitory and of the young woman who keeps the books safe. The winner in the middle-grade category, Alan Gratz's Refugee, contains three stories, one of which focuses on the Holocaust. Rachel DeWoskin's Someday We Will Fly (2020) begins by recounting a family's escape from Europe to Shanghai. While there, the family discovers new people and the value of togetherness. R.J. Palacio's White Bird: A Wonder Story (2020) uses a bully character as a hook into the Holocaust story of Julian's grandmother, reminding the reader that terror is never far away but it can be overcome.

Other difficult topics were tackled in the award-winning books for middle-graders and teens. Dana Reinhardt's The Things a Brother Knows (2011) tells of the return of a soldier from war in the Middle East through the eyes of his younger brother. The novel is a statement on the reluctance to treat PTSD, and how the younger brother (a high-school senior) challenges the perpetrators. Deborah Heiligman's Intentions (2013) is a powerful story about a teenager who discovers that her rabbi is having an extra-marital affair, and has no place to turn.

Five of this decade's award-winning books featured non-Jewish protagonists, including Louise Borden's book about Raoul Wallenberg, the hero of Hungarian Jewry, and Margarita Engle's 
Tropical Secrets. Laura Amy Schlitz's The Hired Girl (2016) features a teenager who moves to Baltimore at the turn of the twentieth century and becomes the household servant for a wealthy Jewish family. Adam Gidwitz's Inquisitor's Tale (2016), set in medieval France, features three children on a pilgrimage: an African boy, a Christian girl, and a Jewish boy. Each of them has a special role in their survival and eventual success. Their journey is recounted in a series of linked stories in the manner of The Canterbury Tales. Alan Gratz's 2018 Refugees follows three children from oppression to freedom; one of them is a German boy escaping the Nazis during World War II, the others are a Cuban girl in the 1990s and a Syrian boy in 2015.

Three winners ( 7 percent) dealt directly with a Jewish holiday: April Wayland's New Year at the Pier (2010) is a story about tashlich, the casting of sins into the water on Rosh Hashanah. Michael Rosen's Hanukkah Lights (2012) celebrates the holiday with a series of elaborate laser-cut pages and very few words. Emily Jenkins's picture book, All of a Kind Family Hanukkah (2018), recreates Sydney Taylor's characters, using the holiday to explore the closeness of family life. Jewish cultural heritage was also represented by folktales. Some of them can be endlessly reinterpreted, employing different narrative methods: Jim Aylesworth's My Grandfather's Coat (2014) tells the same story as Phoebe Gilman's Something from Nothing (1992 picture book awardee) and Simms Taback's Joseph Had a Little Overcoat (STBA Honor Book, 1999). Another popular folkloric element makes an appearance in this decade: Jonathan Auxier's Sweep: The Story of a Girl and Her Monster (2019) combines three unlikely themes: life in Victorian London, a girl-in-a-boy's-job, and a Golem. The result is both touching and enlightening.

Four biographies (13 percent) were awarded during this period. Susan Goldman Rubin's Music Was It (2012) tells the story of Leonard Bernstein's early life through his first evening conducting the New York Philharmonic in 1943. Debbie Levy's I Dissent (2017) is an illustrated and heavily documented picture book describing the life of Justice Ruth Bader Ginsberg. Louise Borden's His Name Was Raoul Wallenberg (2013) provides insight into the terrors of the Holocaust and the bravery needed to save the Jews of Hungary. Richard Michelson's The Language of Angels (2018) is based on the life of Eliezer Ben-Yehuda, who revived and modernized the Hebrew language.

New formats and distinctive graphic design were introduced during this decade. Three ward-winning books were graphic novels or comic books. The first volume in Barry Deutsch's Hereville, recognized in 2011, is fantasy series. Loic Dauvillier's Hidden tells the harrowing story of a French girl who leaves Paris and lives through the war years in the French countryside. The Inquisitor's Tale is illustrated throughout in the style of a medieval manuscript.

Finally, books and reading themselves emerged as a frequent theme for this decade. Sue Macy's The Book Rescuer: How a Mensch from Massachusetts Saved Yiddish Literature for Generations to Come (2020) features Aaron Lansky whose persistence and good fortune led to the success of the Yiddish Book Center. The above-mentioned titles, The Librarian of Auschwitz (2017) and All-of-a-Kind Family Hanukkah (2019), celebrate books and libraries, and-most appropriately - the namesake of AJL's Sydney Taylor Book Award (Table 11). 
R. Leket-Mor and F. Isaac / Judaica Librarianship 21 (2020) 58-94

Table 11. STBA books (2010-2020): Major themes and all themes, aggregated views (30 books)

\begin{tabular}{|c|c|c|c|}
\hline Major Themes (30) & Frequency & All Themes (81) & Frequency \\
\hline Holocaust: survival & 5 & Holocaust & 13 \\
\hline Holocaust & 4 & Family & 9 \\
\hline Family & 3 & Literacy & 4 \\
\hline Holidays & 3 & History & 3 \\
\hline Books & 1 & Holidays & 3 \\
\hline Boxing & 1 & Music & 3 \\
\hline Cats & 1 & Refugees & 3 \\
\hline Child oblates & 1 & Coming of age & 2 \\
\hline Coming of age & 1 & Fantasy \& Magic & 2 \\
\hline $\begin{array}{l}\text { Cultural concept: } \\
\text { Tikkun Olam }\end{array}$ & 1 & Friendship & 2 \\
\hline Fantasy \& Magic & 1 & $\begin{array}{l}\text { Jewish languag- } \\
\text { es }\end{array}$ & 2 \\
\hline Hebrew language & 1 & $\begin{array}{l}\text { Emigration and } \\
\text { immigration }\end{array}$ & 2 \\
\hline Jewish girls & 1 & Animals & 2 \\
\hline Judges & 1 & $\begin{array}{l}\text { Non-frequent } \\
\text { themes }\end{array}$ & 31 \\
\hline Musicians & 1 & & \\
\hline Noah's Ark & 1 & & \\
\hline Refugees & 1 & & \\
\hline Shabbat & 1 & & \\
\hline $\begin{array}{l}\text { Women household } \\
\text { employees }\end{array}$ & 1 & & \\
\hline
\end{tabular}




\section{Award Categories Thematic Review (1981-2020)}

A comparative analysis of the STBA award categories (picture books, middle-grade, and young adult) reveals that beyond the recurring major themes of Holocaust, Emigration and immigration, and Family, picture books often feature holidays while middle-grade books feature comingof-age themes (Table 12). The young adult books exhibit a different picture: While Holocaust and Family are the two most frequent themes, it is impossible to cluster the varied other themes into one inclusive topic as a third frequent theme, which reflects the diversity of books in this award category. The all-theme frequencies (Table 13) provide a complementary perspective of the award categories, again showing that the Holocaust is a major focus of both middle-grade and young adult books, and indicating the dominance of cultural motifs, religious practices, grandparents, and holidays in picture books. (Four of the 11 holiday books are about Hanukkah.) The all-theme lists (Table 16-23, appendix) show additional nuances, such as American heritage and the universal value of friendship in picture books. Middle-grade books retell and anthologize folktales, favor hidden children and stories of escape during the Holocaust, and portray parent-daughter relationships. Books for young adults expand Holocaust-related topics to include other aspects of World War II, and reveal reading itself as a subject.

Table 12. STBA books, first-level themes, aggregated view (102 books)

\begin{tabular}{ccccc}
$\begin{array}{c}\text { Frequency } \\
\text { Level }\end{array}$ & $\begin{array}{c}\text { Original STB Award } \\
10 \text { Books/ Themes }\end{array}$ & $\begin{array}{c}\text { Picture Book } \\
40 \text { Books/ Themes }\end{array}$ & $\begin{array}{c}\text { Middle Grade } \\
38 \text { Books/ Themes }\end{array}$ & $\begin{array}{c}\text { Young Adult } \\
14 \text { Books/ Themes }\end{array}$ \\
\hline 1 & Family & Holidays & Holocaust & Holocaust \\
2 & Antisemitism & Holocaust & $\begin{array}{c}\text { Emigration and } \\
\text { immigration }\end{array}$ & Family \\
3 & $\begin{array}{c}\text { Emigration and immi- } \\
\text { gration }\end{array}$ & $\begin{array}{c}\text { Emigration and } \\
\text { immigration }\end{array}$ & Coming of age & -
\end{tabular}

Table 13. STBA books, all-level themes, aggregated view (102 books)

\begin{tabular}{|c|c|c|c|c|}
\hline Theme Level & $\begin{array}{c}\text { Original STB Award } \\
10 \text { Books/ Themes }\end{array}$ & $\begin{array}{c}\text { Picture Book } \\
40 \text { Books } \\
112 \text { Themes }\end{array}$ & $\begin{array}{c}\text { Middle Grade } \\
38 \text { Books } \\
92 \text { Themes }\end{array}$ & $\begin{array}{c}\text { Young Adult } \\
14 \text { Books } \\
39 \text { Themes }\end{array}$ \\
\hline 1 & Family & Holidays & Holocaust & Holocaust \\
\hline 2 & Antisemitism & $\begin{array}{c}\text { Jewish customs and } \\
\text { practices }\end{array}$ & Holocaust & Holocaust \\
\hline 3 & $\begin{array}{l}\text { Emigration and immi- } \\
\text { gration }\end{array}$ & Grandparents & Escape & Literacy \\
\hline
\end{tabular}




\section{SetTING}

Most of the STBA books (86 percent) are associated with a designated location, with the majority of them described at the country, rather than the city level. Three books describe a dynamic setting, with more than one location (for example, Alan Gratz's Refugee moves from Nazi Germany to Cuba and Syria). Of the 88 STBA books associated with a particular location, 31 books are set in the United States and 35 books are set in European countries (excluding Eastern Europe). Most of the books set in Eastern Europe are original STBA books and middle-grade books. Still, settings of books for middle-grade readers extend across the United Sates (nine books), and other European counties (13 books). Interestingly, the young adult books intended for older readers are the least rooted in location (71 percent), but also feature the most "exotic" locations, including Argentina, Cuba, Shanghai, and Hawaii (Table 24, appendix).

Of the 32 picture books analyzed for story setting, 18 books take place in the United States (one book in New York and four in other states; the other books do not specify the state or city). Seven books are set in small Jewish towns in Eastern Europe (shtetls), which serve as nostalgic locales for holiday or folkloric plots. In her reading of Yiddish literature translated into English (19571973), Ellen Kellman identifies an "Old World sub-genre" in Jewish children's literature, one that tends to include "humor, detailed representation of shtetl culture, and limited portrayals of non-Jews, as well as ... the downplaying of antisemitism, and a focus on child protagonists and the loving family constellation" $(2017,194)$. Our data analyses of the STBA books show that this model was still in use well after the mid-1970s and into the 2010s, in literature originally written in English. Coupled with another picture book trend, namely the socialization of protagonists with grandparents (23 percent of minor themes), the mythical shtetl serves as literary construct that connects the here-and-now with Jewish culture and history. Eichler-Levine notices, too, in her corpus of Hanukkah-Holocaust books $(2010,105)$, "countless examples of grandparents telling stories to their grandchildren - uttering stories in a 'chain' of other stories, particularly in the case of folk wisdom."

\section{Protagonists}

Of the 78 STBA books whose protagonists are clearly described in bibliographic records and book reviews, none depicts Sephardic or Mizrahi Jews, unless the two middle-grade books about the migration of Ethiopian Jews to Israel are considered as such. Other under-represented groups include female protagonists in folktales ( 0 percent) and biographies (33 percent), and adult women in general (6 percent; adult men appear in 16 percent of this subset). Disabled or sick people are hardly represented ( 2 percent), and gender non-conforming people are not represented at all (Figure 3).

Sixty percent of the protagonists in the 32 picture books analyzed for gender are male - of them, ten are boys and nine are either grown men or a single man. The number of girls is almost identical to the number of boys (nine), but only four women are featured among the picture books. Although our study did not rely on textual or visual context and focused on protagonists only, the analyses 
confirm some of Sigalow and Fox's (2014) findings regarding gender representation, division of work, and public practices, and the stereotypes they perpetuate: "The female absence, and hence symbolic annihilation of women in the title and central characters in Jewish children's books, parallels the findings of McCabe et al. (2011). When young boys and girls read stories that disproportionately feature male characters

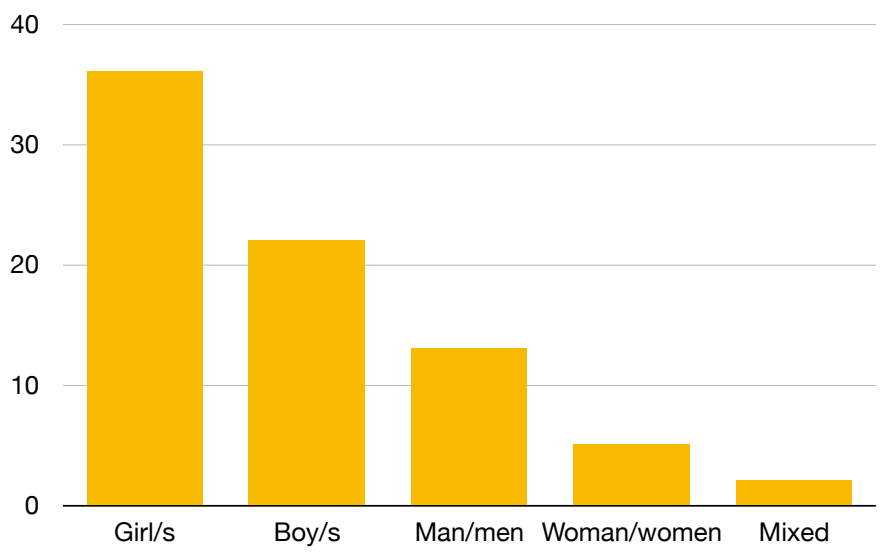

Figure 3. STBA books, protagonist gender (78 books) they may learn that female characters are less important than their male counterparts" (430). ${ }^{17}$ Of these 32 picture books, three girl protagonists are associated with the Holocaust while none of the major themes associated with boy protagonists are Holocaust-related. The same is true for man/men vs. woman/ women protagonists: The Holocaust is associated with females - and holidays with males. In addition, none of the traditional tales set in Eastern European shtetls presents a female protagonist.

A similar trend is noticeable among the 34 middle-grade books that were analyzed for protagonist's gender. Eighteen books (over 50 percent) feature a girl and only ten books feature a boy or boys. ${ }^{18}$ Still, the analysis of Holocaustand immigration-related titles shows that 11 of the 15 protagonists are girls, a disproportionately high number.

These results echo Cummins's (2011) findings, tying positive attributes with male characters in 15 Jewish teen and tween fiction books published in 2005-2009. This study of gender stereotypes in non-STBA corpus concluded that girls are associated with negative attributes such as consumerism and self-improvement while boys are characterized as tolerant and understanding, and as being engaged in social activates that employ ethical behaviors rooted in Judaism (tikkun olam).

\section{The Sydney Taylor Awards and the Holocaust}

The Holocaust is portrayed in 30 of the 102 STBA books. Although the awarded books have differed dramatically in their narrative styles, temporal and geographical settings, and general perspectives, they represent a distinct genre and a growing trend in the middle-grade and young adult categories (Tables 5, 6). The proportion of Holocaust-related books submitted to the SBTA

\footnotetext{
${ }^{17}$ See Sigalow and Fox $(2014,421)$ : "We limited our sample to the young reader award winners because we were primarily interested in how ideas of gender and religion are presented to preschool-aged children who are in the earliest stages of forming their relational, gendered, and religious identities. We evaluated this sample of Jewish children's books through a content analysis of both illustrations and text."

${ }^{18}$ The protagonist's gender is still a determining factor in reading selections at the middle-grade level, especially for boys.
} 
Committee is unknown, but the fact is that they make up almost 30 percent of the awarded books and 45 percent, on average, of the middle-grade and young adult award categories (Table 13). Holocaust-related awarded books are proliferating from three to five annual awardees on average (1970s-1990s) to six in the 2000s and ten in the last decade, even though the last award was added in 2007.

Analyzing the sub-themes that we used for better categorization of the Holocaust-related content reveals that the fate of children in the Holocaust is the major theme (and mostly one of just two themes) of six middle-grade books (Table 15), five of which were awarded between 1994 and 2002. Seven survival narratives form another thematic trend, published across the three award categories and awarded five times in the last decade (two awardees in 2020). The middle-grade awarded titles, in particular, typify the genre of Holocaust books that emphasize children's experiences and survival narratives, or what Haas and Haas $(2008,126)$ call "a rapid development of new children's Holocaust fiction, some of it within the genre of 'coming of age' literature," since the late 1970s. An example for such a Holocaust book model is Donna Napoli's 1997 Stones in Water. It plots the story of an Italian teen who is kidnapped from a movie theater, spends time in a Nazi work camp, and manages to escape; the book follows his dangerous return home. This literary model of middle-grade books also incorporates most of the STBA translated books: Five of the 14 books were translated from other languages (see Figure 1 above); In fact, seven of the eight STBA translated books for middle-grade readers are Holocaust-related.

Table 14. Holocaust books, by award Category (30 books)

\begin{tabular}{lcc}
$\begin{array}{l}\text { Award } \\
\text { Category }\end{array}$ & $\begin{array}{c}\text { Book } \\
\text { Counts }\end{array}$ & $\begin{array}{c}\text { Of Award } \\
\text { Category }\end{array}$ \\
\hline Young Adult & 8 & $57 \%$ \\
$\begin{array}{l}\text { Original STB Award } \\
(1968-1980)\end{array}$ & 4 & $40 \%$ \\
$\begin{array}{l}\text { Middle Grade } \\
\text { Picture Book }\end{array}$ & 14 & $37 \%$ \\
& 4 & $10 \%$
\end{tabular}

Table 15. Original STBA books (19812020): Frequent Holocaust sub-themes, by award Category

\begin{tabular}{lccc}
$\begin{array}{l}\text { Holocaust } \\
\text { Sub-Theme }\end{array}$ & $\begin{array}{c}\text { Picture } \\
\text { Book }\end{array}$ & $\begin{array}{c}\text { Middle } \\
\text { Grade }\end{array}$ & $\begin{array}{c}\text { Young } \\
\text { Adult }\end{array}$ \\
\hline $\begin{array}{l}\text { Children's fate } \\
\begin{array}{l}\text { Concentration } \\
\text { camps }\end{array}\end{array}$ & 2 & 6 & 1 \\
$\begin{array}{l}\text { Survival } \\
\text { nal }\end{array}$ & 1 & 3 & 3
\end{tabular}

Our data show that the 2000s mark the emergence of a new model in Holocaust-related books away from the fate of children and towards such topics as Jewish resistance, refugees, a dybbuk, boxing, Jewish women, death, and hidden children. Examples include Nancy Patz's Who Was the Woman Who Wore the Hat? (2003), a meditation on a personal item seen in a museum. Robert Sharenow's Berlin Boxing Club (2012), an adaptation of a true story that takes place during the late 1930s, recounts the history of the great boxer, Max Schmeling and his sports club, without featuring significant Jewish characters; rather, the book suggests that his gym was an argument for tolerance instead of hatred. The nine-book trend (2003-2015) is followed by the focus on survival in the last five years, as noted above. 
Four picture books about the Holocaust were awarded since the mid-1980s and of them, two feature concentration camps: David Adler's Number on My Grandfather's Arm (1987) and Marci Stillerman's Nine Spoons: A Chanukah Story (1998). As Haas and Haas note (2008, 123), “[S] ome recent picture books for very young children are now becoming much more explicit, portraying Nazi soldiers, concentration camps, hidden children, and other traumatizing events in graphic ways that would have once been deemed unthinkable." Referring to Adler's book, they comment that,

The story is accompanied by black-and-white photographs, which add a somber aura to the story. Yet this is also a somewhat more muted effect than might have been the case, for example, if color pictures had been employed. One of the photographs, however, shows a German soldier pointing a rifle at a mother clutching her baby. Should this have been included? Apparently the editors had a change of heart, since it was removed in the subsequent edition. (127)

The graphic nature of picture books presents challenges to illustrators, educators, and academics alike. Linda Silver, former chair of the Sydney Taylor Book Award Committee, called upon authors to "[S]top writing illustrated books about the Holocaust. With few exceptions, these books serve neither the subject nor the reader. The Holocaust is too profoundly evil to be reduced to 32 heavily illustrated pages and children deserve to have a few years of innocence before they are exposed to the worst of which humans are capable" (Krasner 2010). Eichler (2010) is far more critical, asserting in relation to a Hanukkah-Holocaust book that the holiday is just a cipher for the Holocaust:

The grayscale images of young women prisoners provide a patina of authenticity for readers, suggesting, as the text's narrator does, that this is the real story of the season.... In this way, the contrast of color/sepia stands in for the binary of signifier/signified, reversing the so-called realism of Technicolor: the story that really " is" Hanukkah for the children is the one narrated by their grandmother in black-and-white. (113; italics in the original)

With fewer live witnesses today to the horrors of the Holocaust, debates about meaningful ways to teach the Holocaust are growing. In the context of the literary market, such debates come into play when authors write their manuscripts, when publishers accept them and make decisions about editing and graphic design, and when award committees select winning books. None of these processes is made in a social vacuum. In response to critical comments on social media about the dominance of Holocaust-related books among STBA winners, ${ }^{19}$ the STBA Committee added in early 2020 the following statement to its "How to Submit Books" page (AJL, n.d.): "Particular attention will be paid to titles that demonstrate the broad diversity of the Jewish experience, including diversity of time period and country of origin." Time will tell how these factors are reflected in the book submissions, award selections, and reader and community preferences.

${ }^{19}$ Email communication with Rebecca Levitan, STBA Committee chair, June 24, 2020. 


\section{CONCLUSIONS}

Our project aimed to summarize publishing and thematic trends among the 102 books that received the Sydney Taylor Book Award over its 52-year history. Our measurements relied on catalog records and descriptive book summaries to sort and code book themes, and to identify reoccurring concepts associated with the Jewish experience.

The chronological exploration of the STBA books marks the Holocaust, both on major and minor theme levels, as a growing component of Jewish literature for children and teens. A similar trend is evident in our thematic review of the award categories, where the Holocaust is one of the top themes across the board, on both major and minor theme levels. The middle-grade books that constitute the core of this genre, with almost half of the Holocaust book corpus and over 35 percent of the middle-grade category, were awarded primarily between the mid-1990s and the early 2000s, and tend to focus on the fate of child protagonists. A competing archetype, awarded repeatedly since the mid-2000, is a narrative that tends to be cosmopolitan in terms of its setting and presents the reader with multiple plots. The shift to this Holocaust writing model was accompanied by a focus on survival stories. Holocaust-related books made up nearly all the STBA books translated from other languages, which suggests that American publishers invest in translating international bestsellers that may be marketed to schools. Notably, none of the Holocaust-related books tells the story of Sephardic communities.

Emigration and migration, another historical heritage theme, follows in frequency-again focused exclusively on Ashkenazi Jewry. The theme was popular across existing award categories until the 1990s. Some stories that combine Holocaust survival with a happy ending in America are also associated with grandparents, and the older generation is connected to a traditional Jewish way of life that includes celebrating the holidays and practicing other religious customs. ${ }^{20}$

These themes, also corresponding to nostalgic shtetl stories, constitute a Yiddishkeit motif in STBA picture books, but one that omits the major cultural characteristic of pre-Holocaust Ashkenazi existence in Eastern Europe: the Yiddish language. Only two STBA books relate to Yiddish and only one to Hebrew; all three are picture books published in the last 15 years. American cultural elements are clearly present in many STBA books. Thirty percent of the plots are set in the United States and the country is in the thematic center of three picture books, although the context is chiefly historical. In fact, most of the STBA plots celebrate past events and only a few highlight the present time to explore the current meaning of being Jewish.

Zelkowicz relates the avoidance of discussing the here-and-now in American Jewish education to anxieties over Jewish survival $(2019,150)$ and suggests adopting Vincent Cheng's theory to explain the shift to "cultural nostalgia" (156). Dated perceptions of gender roles, overrepresenta-

\footnotetext{
${ }^{20}$ The predominance of Hanukkah titles in holiday picture books, clearly connected with the elaborateness of Christmas in the United States, calls for a separate discussion which is beyond the scope of this essay. See the short discussion of Hanukkah and Kwanzaa books in this context in Giddens 2019, 95-97.
} 
tion of women and girls, especially in Holocaust-related narratives, and the dearth of groups such as Sephardic, Orthodox, and secular Jews, or disabled, gender non-conforming, people of color, or other marginalized communities - indicate that there is a lot of unexplored terrain in Jewish children's literature, particularly with respect to modern society and inclusivity, but also present exciting challenges for future authors, illustrators, translators, and publishers, and perhaps also for STBA Committee members.

With every review cycle, the STBA Committee evaluates over a hundred books (Kamin 2008, 38) that interpret the Jewish experience for children and teens. The choice of awarded books depends on a number of factors, including the makeup of the committee, which is updated annually with new volunteer members; written and unwritten evaluation criteria (Banks and Silverman 2006; Pinchuck 2008, 30 lists several and refers to evaluating and reviewing criteria compiled with Rachel Kamin in an undated document); and the standards exemplified in previously awarded books. The STBA selections affect the AJL community, which includes librarians, teachers, and parents who acquire awarded books for their institutional libraries or their homes. Indeed, the STBA books form the canon of Jewish children's literature, which is also collected and preserved in public and research libraries to serve audiences broader than their targeted readership (see, for example, Taler 2011; Sharma and Christ 2017).

The STBA Committee depends, of course, on the newly-published book inventory, which is the end product of a long decision-making and operational chain of events. Unlike the STBA Committee, publishers are motivated by both political and commercial considerations, which may affect every aspect of the final book, from the style of the illustrations to the tiniest textual element. But publishers are also affected by the decisions of award committees. This reciprocal relationship is then the answer to the rhetorical question, "Who are the agents and players and stakeholders of prizing, including but not limited to those who select and administer prizes? How do particular systems or networks of value and evaluation work?" (Kidd and Thomas 2017, 14). The book award ecosystem involves authors, illustrators, editors, book reviewers, journalists, educators and educational administrators, parents, and librarians. The complexity of such cultural systems makes it difficult to know if and how authors replicate models of past award winners, how manuscripts are selected for publication, or if and how texts are modified during the editing process in adherence to perceived award standards. Any or all of these processes could result in new trends in STBA books, such as the growing multidimensionality seen in recent publications.

The books awarded by the STBA Committee are the concern of all who care about Jewish literature and education. We hope that this study will help preserve this canon and expand its didactic boundaries to serve the informational and emotional needs of young readers, as they explore their own and others' identity in the twenty-first century. We also hope that our methodology and datasets will prove useful for future research, such as gender studies or comparative studies of the entire STBA corpus. 


\section{SOURCES}

AJL (Association of Jewish Libraries). n.d. "Sydney Taylor Book Award." Accessed March 24, 2020. https://jewishlibraries.org/Sydney_Taylor_Book_Award.

Banks, Cheryl and Lisa Silverman. 2006. “The Quest for Excellence in Jewish Children's Literature.” Judaica Librarianship 12: 69-78. http://dx.doi.org/10.14263/2330-2976.1098.

Bickmore, Steven, Yunying Xu, and Myra Sheridan. 2017. "Where Are the People of Color?: Representation of Cultural Diversity in the National Book Award for Young People's Literature and Advocating for Diverse Books in a Non-Post Racial Society." Taboo 16 (1): 39-54. https://doi.org/10.31390/taboo.16.1.06.

Bones, Gail. 2010. "The Six Pillars of Character in $21^{\text {st }}$ Century Newbery Award Books.” PhD Diss., Liberty University. http://search.proquest.com/docview/743818398/?pq-orig$\underline{\text { site }=\text { primo. }}$.

Cummins, June. 2017. “The Still Almost All-White World of Children's Literature: Theory, Practice, and Identity-Based Children's Book Awards," in Prizing Children's Literature: The Cultural Politics of Children's Book Awards, edited by Kenneth B. Kidd and Joseph T. Thomas, 101-117. New York: Routledge.

—. 2011. "What Are Jewish Boys and Girls Made of?: Gender in Contemporary Jewish Teen and Tween Fiction." Children's Literature Association Quarterly 36 (3): 296-317. https://muse.jhu.edu/article/448047.

Eichler-Levine, Jodi. 2010. "The Curious Conflation of Hanukkah and the Holocaust in Jewish Children's Literature." Shofar 28 (2): 92-115. www.jstor.org/stable/10.5703/shofar.28.2.92.

Forest, Danielle E. 2014. "From Rags to 'Rich as Rockefeller': Portrayals of Class Mobility in Newbery Titles.” Curriculum Inquiry 44 (5): 591-619. https://doi.org/10.1111/ curi.12067.

Forest, Danielle E., Kasey L. Garrison, and Sue C. Kimmel. 2015. "'The University for the Poor': Portrayals of Class in Translated Children's Literature.” Teachers College Record 117.2: 1-40. https://trove.nla.gov.au/version/262230044.

Giddens, Eugene. 2019. Christmas Books for Children. Cambridge: Cambridge University Press.

Haas, Peter J., and Lee W. Haas. 2008. “"Thou Shalt Teach It to Thy Children’: What American Jewish Children's Literature Teaches about the Holocaust," in The Impact of the Holo- 
caust in America, edited by Bruce Zukerman, 119-137. West Lafayette, Indiana: Purdue University Press.

Jiménez, Laura M. 2015. "Representations in Award-Winning LGBTQ Young Adult Literature from 2000-2013." Journal of Lesbian Studies 19 (4): 406-422. https://doi.org/10.1080/ $\underline{10894160.2015 .1057795 .}$.

Kamin, Rachel. 2008. "The 2008 Sydney Taylor Book Awards: An Overview.” Judaica Librarianship 14 (1): 35-38. https://doi.org/10.14263/2330-2976.1072.

Kellman, Ellen D. 2017. "Constructing the Eastern European Jewish Past in Post-Holocaust Children's Literature (1950-1975)," in Reconstructing the Old Country; American Jewry in the Post-Holocaust Decades, edited by Eliyana R. Adler and Sheila E. Jelen, 173-198. Detroit: Wayne State University Press.

Kidd, Kenneth B., and Joseph T. Thomas. 2017. Prizing Children's Literature: The Cultural Politics of Children's Book Awards. New York: Routledge.

Koss, Melanie, Nancy Johnson, and Miriam Martinez. 2018. "Mapping the Diversity in Caldecott Books from 1938 to 2017: The Changing Topography." Journal of Children's Literature 44 (1): 4-20.

Krasner, Barbara. 2010. "Interview with Linda R. Silver," The Whole Megillah Librarian's Notebook blog. August 18, 2010. https://thewholemegillah.wordpress.com/2010/08/18/librarians-notebook-linda-r-silver/.

Martin, Kimberly Bartels. 1990. "A Descriptive View of the Portrayal of Jewish and Christian Lifestyles in Award-Winning Children's Books from 1960 to 1990 Using Content Analysis.” Master's thesis, Ball State University. https://eric.ed.gov/?id=ED336742.

Pinchuck, Kathe. 2008. “Recognizing Jewish Children's Literature for Forty Years: The Sydney Taylor Book Award." Judaica Librarianship 14: 27-34. https://doi.org/10.14263/23302976.1071.

(ed.). 2018. The Sydney Taylor Book Award: A Guide to the Winners, Honor Books and Notables. 50 ${ }^{\text {th }}$ Anniversary Edition, 1968-2018. Association of Jewish Libraries.

Rowland-Storm, Cuthbert. 2018. "Problematizing the Promises of the American Library Association's Awards That Recognize Difference." PhD Diss. The Pennsylvania State University. http://search.proquest.com/docview/2160635969/?pq-origsite=primo.

Sigalow, Emily, and Nicole S. Fox. 2014. "Perpetuating Stereotypes: A Study of Gender, Family, 
and Religious Life in Jewish Children's Books." Journal for the Scientific Study of Religion 53 (2): 416-431. https://doi.org/10.1111/jssr.12112.

Taler, Izabella. 2011. "The Jewish Studies Book Awards: A Collection Development Strategy for Non-Sectarian Academic Libraries." Collection Building 30 (1): 11-38. https://doi. org/10.1108/01604951111104998.

Turner, Treva. 1973. “Cataloging Children's Materials at the Library of Congress." The Quarterly Journal of the Library of Congress 30 (2): 152-157. www.jstor.org/stable/29781542.

Sharma, Sue Ann, and Tanya Christ. 2017. "Five Steps Toward Successful Culturally Relevant Text Selection and Integration.” The Reading Teacher 71 (3): 295-307. https://doi. org/10.1002/trtr.1623.

Zelkowicz, Tali. 2019. “Jewish Educators Don't Make Jews: A Sociological Reality Check about Jewish Identity Work," in Beyond Jewish Identity: Rethinking Concepts and Imagining Alternatives, edited by Jon A. Levisohn and Ari Y. Kelman, 144-166. Boston: Academic Studies Press. https://bir.brandeis.edu/bitstream/handle/10192/37472/9781644691298 Print.pdf? sequence=1\&isAllowed=y\#page $=164$. 


\section{Appendix: Supplemental Tables}

Table 16. Original STB Award books (1968-1980): 30 themes, in alphabetical order (10 books)

\begin{tabular}{|c|c|c|c|}
\hline Themes & Frequency & Themes & Frequency \\
\hline Antisemitism & 2 & Antisemitism & 2 \\
\hline \multirow{2}{*}{ Coming of age } & \multirow{2}{*}{1} & Baal Shem Tov & 1 \\
\hline & & Bears & 1 \\
\hline Disabled children & 1 & Brothers & 1 \\
\hline $\begin{array}{l}\text { Emigration and } \\
\text { immigration }\end{array}$ & 1 & $\begin{array}{l}\text { Customs and prac- } \\
\text { tices: Shiva }\end{array}$ & 1 \\
\hline Exiles & 1 & Death & 1 \\
\hline Families & 1 & Emigration & 3 \\
\hline Family life & 1 & $\begin{array}{l}\text { Emigration and } \\
\text { immigration }\end{array}$ & 2 \\
\hline Friendship & 1 & & \\
\hline $\begin{array}{l}\text { Holocaust: Jewish } \\
\text { resistance }\end{array}$ & 1 & $\begin{array}{l}\text { Escape } \\
\text { Ethiopian Jews }\end{array}$ & $\begin{array}{l}1 \\
1\end{array}$ \\
\hline \multirow{2}{*}{$\begin{array}{l}\text { Immigrant tene- } \\
\text { ment life }\end{array}$} & \multirow{2}{*}{1} & Family life & 2 \\
\hline & & Folk tales & 1 \\
\hline Immigration & 1 & Folklore & 1 \\
\hline \multirow{3}{*}{$\begin{array}{l}\text { Interpersonal } \\
\text { relations } \\
\text { Jewish immigration } \\
\text { from Russia }\end{array}$} & 1 & Friendship & 2 \\
\hline & \multirow{2}{*}{1} & Grandmothers & 3 \\
\hline & & Grandparents & 1 \\
\hline Nazis & 1 & Historical fiction & 1 \\
\hline Neighborliness & 1 & Holidays: Hanukkah & 1 \\
\hline No 2nd theme & 1 & $\begin{array}{l}\text { Holidays: Yom } \\
\text { Kippur }\end{array}$ & 1 \\
\hline No 3rd theme & 5 & & \\
\hline Orphans & 1 & & \\
\hline Persecutions & 1 & & \\
\hline $\begin{array}{l}\text { Politics and gov- } \\
\text { ernment }\end{array}$ & 1 & & \\
\hline Slave labor & 1 & & \\
\hline Weddings & 1 & & \\
\hline $\begin{array}{l}\text { World War, } \\
\text { 1939-1945 }\end{array}$ & 2 & & \\
\hline $\begin{array}{l}\text { Young volunteers } \\
\text { in kibbutzim }\end{array}$ & 1 & & \\
\hline
\end{tabular}

Table 17. STBA books (1981-1990): 60 themes, in alphabetical order (20 books)

\begin{tabular}{lc} 
Themes & Frequency \\
\hline $\begin{array}{l}\text { Holocaust survivors } \\
\text { Holocaust: chil- } \\
\text { dren's fate }\end{array}$ & 1 \\
$\begin{array}{l}\text { Holocaust: concen- } \\
\text { tration camps }\end{array}$ & 2 \\
Holocaust: survival & 3 \\
Humor & 1 \\
Immigration & 1 \\
Labor movement in & 1 \\
America & \\
Legends & 2 \\
Mothers and daugh- & 1 \\
ters & 1 \\
Mothers and sons & 1 \\
Moving & 1 \\
No 2nd theme & 1 \\
No 3rd theme & 7 \\
Persecutions & 1 \\
Personal Narrative & 2 \\
Poor people & 1 \\
Prayers & 1 \\
Quilts & 1 \\
Shabbat & 2 \\
Time travel & 1 \\
&
\end{tabular}


Table 18. STBA books (1991-1999): 57 themes, in alphabetical order (19 books)

\begin{tabular}{|c|c|c|c|}
\hline Themes & Frequency & Themes & Frequency \\
\hline Antisemitism & 1 & \multirow{2}{*}{$\begin{array}{l}\text { Holocaust: children's } \\
\text { fate }\end{array}$} & \multirow{2}{*}{3} \\
\hline Coming of age & 1 & & \\
\hline Courage & 1 & Holocaust: concen- & 1 \\
\hline $\begin{array}{l}\text { Cultural Concepts: } \\
\text { Teshuvah }\end{array}$ & 1 & $\begin{array}{l}\text { tration camps } \\
\text { Holocaust: friendship }\end{array}$ & 1 \\
\hline \multirow{2}{*}{$\begin{array}{l}\text { Customs and practic- } \\
\text { es: Shiva }\end{array}$} & \multirow{2}{*}{1} & Holocaust: survival & 1 \\
\hline & & Humor & 1 \\
\hline Death & 1 & Immigration & 1 \\
\hline Elijah & 1 & Israel & 1 \\
\hline Emigration & 1 & Legends & 1 \\
\hline \multirow{2}{*}{$\begin{array}{l}\text { Emigration and immi- } \\
\text { gration }\end{array}$} & \multirow{2}{*}{1} & Nazi regime & 1 \\
\hline & & No 2nd theme & 1 \\
\hline Escape & 2 & No 3rd theme & 8 \\
\hline Ethiopian Jews & 1 & Peddlers & 1 \\
\hline Families & 1 & \multirow{2}{*}{$\begin{array}{l}\text { People with disabil- } \\
\text { ities }\end{array}$} & \multirow{2}{*}{1} \\
\hline Farm life & 1 & & \\
\hline Folk tales & 1 & \multirow{2}{*}{$\begin{array}{l}\text { Political assassina- } \\
\text { tion }\end{array}$} & \multirow{2}{*}{1} \\
\hline Folklore & 2 & & \\
\hline France & 1 & Prime ministers & 1 \\
\hline Ghosts & 1 & Racism & 1 \\
\hline Grandfathers & 1 & Ritual objects: Tallith & 1 \\
\hline Grandmothers & 1 & Tales & 1 \\
\hline Grandparents & 2 & Torah & 1 \\
\hline Hidden children & 1 & & \\
\hline Holidays & 1 & & \\
\hline Holidays: Hanukkah & 2 & & \\
\hline Holidays: Purim & 1 & & \\
\hline $\begin{array}{l}\text { Holidays: Simchat } \\
\text { Torah }\end{array}$ & 1 & & \\
\hline
\end{tabular}


Table 19. STBA books (2000-2009): 69 themes, in alphabetical order

\begin{tabular}{|c|c|c|c|}
\hline Themes & Frequency & Themes & Frequency \\
\hline 1933-1945 & 1 & Holocaust & 1 \\
\hline African Ameri- & 1 & Holocaust poetry & 1 \\
\hline cans & 1 & Holocaust: chil- & \\
\hline American culture & 1 & dren's fate & 2 \\
\hline American history & 1 & Holocaust: Jew- & 1 \\
\hline Arab-Israeli & 1 & ish women & 1 \\
\hline conflict & 1 & Holocaust: refu- & 1 \\
\hline Authors & 1 & gees & 1 \\
\hline Bedtime & 1 & Identity & 2 \\
\hline $\begin{array}{l}\text { Caring and } \\
\text { friendship }\end{array}$ & 2 & $\begin{array}{l}\text { Immigrant expe- } \\
\text { rience }\end{array}$ & 1 \\
\hline Catholic Church & 1 & Immigration & 1 \\
\hline Civil rights & 1 & Interpersonal & 1 \\
\hline Coming of age & 2 & relations & \\
\hline Conduct of life & 1 & Israelis & 1 \\
\hline Cooking & 1 & Judaism & 1 \\
\hline Cousins & 1 & No 2nd theme & 1 \\
\hline Cuba Jews & 1 & No 3rd theme & 7 \\
\hline Cultural concept: & & Prayers & 1 \\
\hline Tashlich & 1 & Psychoanalysis & 1 \\
\hline Cultural con- & & Psychoanalysts & 1 \\
\hline cepts: Teshuvah & 1 & Religion & 1 \\
\hline Death & 1 & Sickness & 1 \\
\hline Dybbuk & 1 & Social justice & 1 \\
\hline Family life & 2 & Storytelling & 1 \\
\hline Father-daughter & & Terrorism & 1 \\
\hline relationship & 1 & Toleration & 1 \\
\hline Forgiveness & 1 & Traditional & 1 \\
\hline Friendship & 2 & foods: bagels & 1 \\
\hline $\begin{array}{l}\text { George Wash- } \\
\text { ington }\end{array}$ & 1 & $\begin{array}{l}\text { Traditional } \\
\text { foods: chicken }\end{array}$ & 1 \\
\hline Ghost stories & 1 & soup & \\
\hline God & 1 & Yiddish lan- & 1 \\
\hline Hidden children & 1 & guage & \\
\hline $\begin{array}{l}\text { Holidays: Ha- } \\
\text { nukkah }\end{array}$ & 1 & & \\
\hline $\begin{array}{l}\text { Holidays: Rosh } \\
\text { ha-Shanah }\end{array}$ & 1 & & \\
\hline $\begin{array}{l}\text { Holidays: } \\
\text { Thanksgiving }\end{array}$ & 1 & & \\
\hline $\begin{array}{l}\text { Holidays: Yom } \\
\text { Kippur }\end{array}$ & 1 & & \\
\hline
\end{tabular}


Table 20. STBA books (2010-2020): 90 themes, in alphabetical order (30 books)

\begin{tabular}{|c|c|c|c|}
\hline Themes & Frequency & Themes & Frequency \\
\hline Action \& Adventure & 1 & Holocaust & 1 \\
\hline Adaptations & 1 & Holocaust: atrocities & 1 \\
\hline Adolf Eichmann & 1 & $\begin{array}{l}\text { Holocaust: concen- } \\
\text { tration camps }\end{array}$ & 1 \\
\hline Adultery & 1 & & \\
\hline American culture & 1 & $\begin{array}{l}\text { Holocaust: hidden } \\
\text { children }\end{array}$ & 1 \\
\hline Animals & 1 & Holocaust: refugees & 1 \\
\hline Argentina & 1 & Holocaust: survival & 6 \\
\hline Biblical events & 1 & Homeless persons & 1 \\
\hline Books & 2 & & \\
\hline Books and libraries & 1 & Immigration & 1 \\
\hline Boxing & 1 & Jewish family & 1 \\
\hline Brothers & 1 & Jewish girls & 1 \\
\hline Cats & 1 & Judges & 1 \\
\hline Child oblates & 1 & Language revival & 1 \\
\hline Circus performance & 1 & Music composition & 1 \\
\hline Clothing & 1 & Musicians & 2 \\
\hline Coming of age & 2 & Nazis & 1 \\
\hline Counting & 1 & No 2nd theme & 1 \\
\hline Cultural concept: & & No 3rd theme & 8 \\
\hline Tikkun Olam & 1 & Noah's Ark & 1 \\
\hline Dissent & 1 & $\begin{array}{l}\text { Persecutions (Middle } \\
\text { Ages) }\end{array}$ & 1 \\
\hline Drinking cups & 1 & Post-traumatic stress & 1 \\
\hline Emigration and & 1 & disorder & \\
\hline & & Reading & 1 \\
\hline Families & 1 & Refugees & 2 \\
\hline Family life & 3 & Responsibility & 1 \\
\hline Fantasy & 1 & Righteous Gentiles & 1 \\
\hline Fantasy \& Magic & 1 & Shabbat & 1 \\
\hline Friars & 1 & Slavery & 1 \\
\hline Friendship & 2 & Social justice & 1 \\
\hline Golem & 1 & Survival & 1 \\
\hline Grandfathers & 1 & Way of life & 1 \\
\hline Grandmothers & 1 & Women household & \\
\hline Hebrew language & 1 & employees & 1 \\
\hline Historical fiction & 1 & World War, 1939_- & \\
\hline History & 3 & 1945 & 1 \\
\hline Holidays: Hanukkah & 2 & Yiddish language & 1 \\
\hline Holidays: Passover & 1 & & \\
\hline
\end{tabular}


Table 21. STBA books, picture book category: 120 themes, in alphabetical order (40 books)

\begin{tabular}{|c|c|c|c|c|c|}
\hline 1-Level Themes & Frequency & 2-Level Themes & Frequency & 3-Level Themes & Frequency \\
\hline Adaptations & 1 & American culture & 1 & African Americans & 1 \\
\hline Books & 1 & American history & 1 & American culture & 1 \\
\hline \multirow{2}{*}{$\begin{array}{l}\text { Caring and friend- } \\
\text { ship }\end{array}$} & \multirow{2}{*}{1} & Authors & 1 & Baal Shem Tov & 1 \\
\hline & & Bears & 1 & Books & 1 \\
\hline Cats & 1 & Bedtime & 1 & Brothers & 1 \\
\hline \multirow{2}{*}{$\begin{array}{l}\text { Cultural concept: } \\
\text { Tikkun Olam }\end{array}$} & \multirow{2}{*}{1} & Biblical events & 1 & \multirow{2}{*}{$\begin{array}{l}\text { Cultural concepts: } \\
\text { Teshuvah }\end{array}$} & \multirow{2}{*}{2} \\
\hline & & Caring and friendship & 1 & & \\
\hline Death & 2 & Civil rights & 1 & Dissent & 1 \\
\hline $\begin{array}{l}\text { Emigration and } \\
\text { immigration }\end{array}$ & \multirow[t]{2}{*}{1} & Clothing & 1 & \multirow{2}{*}{$\begin{array}{l}\text { Emigration and } \\
\text { immigration }\end{array}$} & \multirow[b]{2}{*}{1} \\
\hline Family life & & Counting & 1 & & \\
\hline Folklore & 1 & $\begin{array}{l}\text { Cultural concept: } \\
\text { Tashlich }\end{array}$ & \multirow[t]{2}{*}{1} & \multirow{2}{*}{$\begin{array}{l}\text { Families } \\
\text { Forgiveness }\end{array}$} & 1 \\
\hline Hebrew language & 1 & \multirow{2}{*}{$\begin{array}{l}\text { Customs and practic- } \\
\text { es: Shiva }\end{array}$} & & & \multirow[b]{2}{*}{1} \\
\hline Holidays & 1 & & 2 & France & \\
\hline Holidays: Hanukkah & 4 & Family life & 1 & Friendship & 1 \\
\hline Holidays: Passover & 1 & Friendship & 2 & George Washington & 1 \\
\hline Holidays: Purim & 1 & God & 1 & Grandfathers & 2 \\
\hline \multirow{2}{*}{$\begin{array}{l}\text { Holidays: Rosh } \\
\text { ha-Shanah }\end{array}$} & \multirow{2}{*}{1} & Grandparents & 3 & Grandmothers & 4 \\
\hline & & Greed & 1 & History & 3 \\
\hline \multirow{2}{*}{$\begin{array}{l}\text { Holidays: Simchat } \\
\text { Torah }\end{array}$} & \multirow[t]{2}{*}{1} & Hasidism & 1 & Humor & 2 \\
\hline & & Historical fiction & 1 & Judaism & 1 \\
\hline $\begin{array}{l}\text { Holidays: Yom } \\
\text { Kippur }\end{array}$ & 2 & Holidays: Hanukkah & 2 & No 3rd theme & 8 \\
\hline Holocaust: concen- & & Holidays: Thanksgiv- & 1 & Personal narratives & 1 \\
\hline tration camps & 2 & & & $\begin{array}{l}\text { Political assassina- } \\
\text { tion }\end{array}$ & 1 \\
\hline Holocaust: friend- & 1 & Holocaust survivors & 1 & Poor people & \\
\hline ship & 1 & Judaism & 1 & & 1 \\
\hline Holocaust: survival & 1 & Language revival & 1 & Slavery & 1 \\
\hline Immigration & 2 & Moving & 1 & $\begin{array}{l}\text { Traditional foods: } \\
\text { bagels }\end{array}$ & 1 \\
\hline Israel & 1 & Music composition & 1 & Traditional foods: & \\
\hline Judges & 1 & Nazi regime & 1 & chicken soup & 1 \\
\hline Legends & 1 & People with disabilities & 1 & & \\
\hline Peddlers & 1 & Prayers & 1 & & \\
\hline Prayers & 1 & Prime ministers & 1 & & \\
\hline Ritual objects: & & Quilts & 1 & & \\
\hline Tallith & 1 & Social justice & 1 & & \\
\hline Shabbat & 3 & Torah & 1 & & \\
\hline Sickness & 1 & Way of life & 1 & & \\
\hline Social justice & 1 & Yiddish language & 1 & & \\
\hline Yiddish language & 1 & & & & \\
\hline
\end{tabular}


R. Leket-Mor and F. Isaac / Judaica Librarianship 21 (2020) 58-94

Table 22. STBA books, middle-grade category: 114 themes, in alphabetical order (38 books)

\begin{tabular}{|c|c|c|c|c|c|}
\hline 1-Level Themes & Frequency & 2-Level Themes & Frequency & 3-Level Theme & Frequency \\
\hline Antisemitism & 1 & Action \& Adventure & 1 & Antisemitism & 1 \\
\hline Catholic Church & 1 & Antisemitism & 1 & Courage & 1 \\
\hline Child oblates & 1 & Conduct of life & 1 & Drinking cups & 1 \\
\hline Coming of age & 3 & Cooking & 1 & \multirow{2}{*}{$\begin{array}{l}\text { Emigration and immi- } \\
\text { gration }\end{array}$} & \multirow[t]{2}{*}{1} \\
\hline Dybbuk & 1 & Emigration & 1 & & \\
\hline Elijah & 1 & Escape & 1 & \multirow{2}{*}{$\begin{array}{l}\text { Escape } \\
\text { Familv life }\end{array}$} & 2 \\
\hline Emigration & 3 & Fantasy & 1 & & 1 \\
\hline Emigration and & 1 & Farm life & 1 & $\begin{array}{l}\text { Father-daughter } \\
\text { relationship }\end{array}$ & 1 \\
\hline \multirow{2}{*}{ Ethiopian Jews } & \multirow{2}{*}{2} & Folk tales & 2 & \multirow{2}{*}{$\begin{array}{l}\text { Friars } \\
\text { Ghosts }\end{array}$} & 1 \\
\hline & & Friendship & 1 & & 1 \\
\hline Family life & 3 & Ghost stories & 1 & Grandmothers & 1 \\
\hline Fantasy \& Magic & 1 & Golem & 1 & Holocaust & 1 \\
\hline Friendship & 1 & Hidden children & 2 & Homeless persons & 1 \\
\hline Holocaust & 1 & Holocaust poetry & 1 & \multirow{2}{*}{$\begin{array}{l}\text { Identity } \\
\text { Interpersonal rela- } \\
\text { tions }\end{array}$} & 1 \\
\hline $\begin{array}{l}\text { Holocaust: children's } \\
\text { fate }\end{array}$ & 6 & $\begin{array}{l}\text { Holocaust: children's } \\
\text { fate }\end{array}$ & 1 & & 1 \\
\hline $\begin{array}{l}\text { Holocaust: concen- } \\
\text { tration camps }\end{array}$ & 1 & Holocaust: survival & 3 & Israelis & 1 \\
\hline Holocaust: hidden & & Identity & 1 & Legends & 1 \\
\hline children & 1 & Immigrant experience & 1 & Mothers and daugh- & 1 \\
\hline Holocaust: Jewish & 1 & Immigration & 2 & ters & \\
\hline women & 1 & Labor movement in & 1 & No 3rd theme & 18 \\
\hline Holocaust: survival & 3 & America & & Personal Narrative & 1 \\
\hline Jewish girls & 1 & Mothers and sons & 1 & Time travel & 1 \\
\hline Legends & 2 & No 2nd theme & 4 & & \\
\hline Musicians & 1 & Persecutions & 1 & & \\
\hline Psychoanalysis & 1 & Persecutions (Middle & 1 & & \\
\hline Refugees & 1 & Ages) & & & \\
\hline & & Psychoanalysts & 1 & & \\
\hline & & Racism & 1 & & \\
\hline & & Refugees & 1 & & \\
\hline & & Righteous Gentiles & 1 & & \\
\hline & & Tales & 1 & & \\
\hline & & Terrorism & 1 & & \\
\hline
\end{tabular}


R. Leket-Mor and F. Isaac / Judaica Librarianship 21 (2020) 58-94

Table 23. STBA books, young adult category: 39 themes, in alphabetical order (14 books)

\begin{tabular}{|c|c|c|c|c|c|}
\hline 1-Level Theme & Frequency & 2-Level Themes & Frequency & 3-Level Themes & Frequency \\
\hline Adolf Eichmann & 1 & $1933-1945$ & 1 & Animals & 1 \\
\hline Arab-Israeli conflict & 1 & Adultery & 1 & Argentina & 1 \\
\hline Boxing & 1 & Books and libraries & 1 & Brothers & 1 \\
\hline Coming of age & 1 & Coming of age & 1 & Circus performance & 1 \\
\hline Cousins & 1 & Cuba Jews & 1 & Historical fiction & 1 \\
\hline Death & 1 & Families & 1 & Musicians & 1 \\
\hline Family life & 1 & Friendship & 1 & Nazis & 1 \\
\hline \multirow{2}{*}{$\begin{array}{l}\text { Holocaust: concentra- } \\
\text { tion camps }\end{array}$} & \multirow{2}{*}{1} & Holocaust: atrocities & 1 & No 3rd theme & 3 \\
\hline & & Holocaust: refugees & 1 & Reading & 1 \\
\hline \multirow{3}{*}{$\begin{array}{l}\text { Holocaust: refugees } \\
\text { Holocaust: survival } \\
\text { Noah's Ark }\end{array}$} & 1 & Jewish family & 1 & Religion & 1 \\
\hline & 3 & \multirow{2}{*}{$\begin{array}{l}\text { Post-traumatic stress } \\
\text { disorder }\end{array}$} & \multirow{2}{*}{1} & Responsibility & 1 \\
\hline & 1 & & & Storytelling & 1 \\
\hline \multirow{3}{*}{$\begin{array}{l}\text { Women household } \\
\text { employees }\end{array}$} & \multirow[t]{3}{*}{1} & Survival & 1 & & \\
\hline & & Toleration & 1 & & \\
\hline & & $\begin{array}{l}\text { World War, 1939- } \\
1945\end{array}$ & 1 & & \\
\hline
\end{tabular}


R. Leket-Mor and F. Isaac / Judaica Librarianship 21 (2020) 58-94

Table 24. STBA books (1968-2020): Setting, by award category with associated location

\begin{tabular}{|c|c|c|c|c|c|}
\hline Setting & $\begin{array}{c}\text { Original STB Award } \\
10 \text { Books }\end{array}$ & $\begin{array}{l}\text { Picture Book } \\
32 \text { Books }\end{array}$ & $\begin{array}{l}\text { Middle Grade } \\
36 \text { Books }\end{array}$ & $\begin{array}{l}\text { Young Adult } \\
10 \text { Books }\end{array}$ & Total \\
\hline Eastern European Shtetl & & 7 & & & 7 \\
\hline Europe & & & 3 & & 3 \\
\hline France & & 2 & 3 & & 5 \\
\hline Netherlands & & & 3 & & 3 \\
\hline Austria & 1 & & 1 & & 2 \\
\hline Germany & 1 & & & 1 & 2 \\
\hline Berlin & & & & 1 & 1 \\
\hline Denmark & & & 1 & & 1 \\
\hline England & & & 1 & & 1 \\
\hline England/ United States & 1 & & & & 1 \\
\hline Italy & & & 1 & & 1 \\
\hline $\begin{array}{l}\text { Nazi Germany; Cuba; } \\
\text { Syria }\end{array}$ & & & 1 & & 1 \\
\hline Russia & 1 & 1 & 5 & & 7 \\
\hline Poland & & & 3 & 2 & 5 \\
\hline Ukraine & 1 & & 1 & & 2 \\
\hline Soviet Siberia & 1 & & & & 1 \\
\hline Soviet Union & 1 & & & & 1 \\
\hline Czech Republic & & & 1 & & 1 \\
\hline Shanghai, China & & & & 1 & 1 \\
\hline Argentina & & & & 1 & 1 \\
\hline Cuba & & & & 1 & 1 \\
\hline Israel & 1 & 3 & 1 & 1 & 6 \\
\hline Biblical Egypt & & 1 & & & 1 \\
\hline Ethiopia & & & 2 & & 2 \\
\hline United States & & 13 & 7 & & 20 \\
\hline New York/ Brooklyn & 2 & 2 & 1 & & 5 \\
\hline Pennsylvania, Baltimore & & & & 1 & 1 \\
\hline $\begin{array}{l}\text { Massachusetts -- New } \\
\text { Bedford }\end{array}$ & & 1 & & & 1 \\
\hline Minnesota & & 1 & & & 1 \\
\hline Southern US & & & 1 & & 1 \\
\hline Wyoming & & 1 & & & 1 \\
\hline Hawaii & & & & 1 & 1 \\
\hline
\end{tabular}

